creasing up to 1 c.c., or even more in some cases. When the cancerous growth has been eliminated treatment is stopped. The frequency with which injections are given depends on the amount of reaction produced. Arthur J. Hutchison.

\title{
NEW INSTRUMENTS.
}

A Wool TIDy.-This instrument consists of a serrated scraper for the easy removal of cotton-wool from probes, forceps, etc. It is firmly secured to the table by means of screws which pass through slots in the foot-plate, but it is readily detachable.

The wool is easily removed with one hand only by simply dragging the applicator firmly through one of the clefts with a slight rotatory
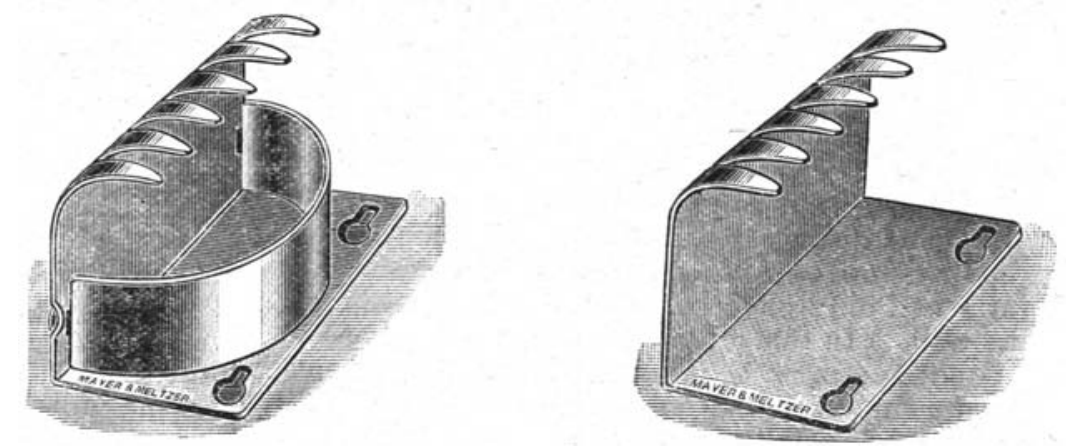

movement, a somewhat difficult feat with the usual metal box, which, owing to its unsteadiness, demands the use of both hands.

It is made by Messrs. Mayer and Meltzer in two shapes, with and without a well, which is detachable for sterilizing purposes.

Although specially designed for aural and nasal work, it will be found to be equally serviceable in dental and other work which requires the use of wool wads for cleansing and escharotic treatment.

Wyatt Wingrave. 
JOURAAL OF LARYAGOLOGY, RHINOLOGY, AND OTOLOGY.

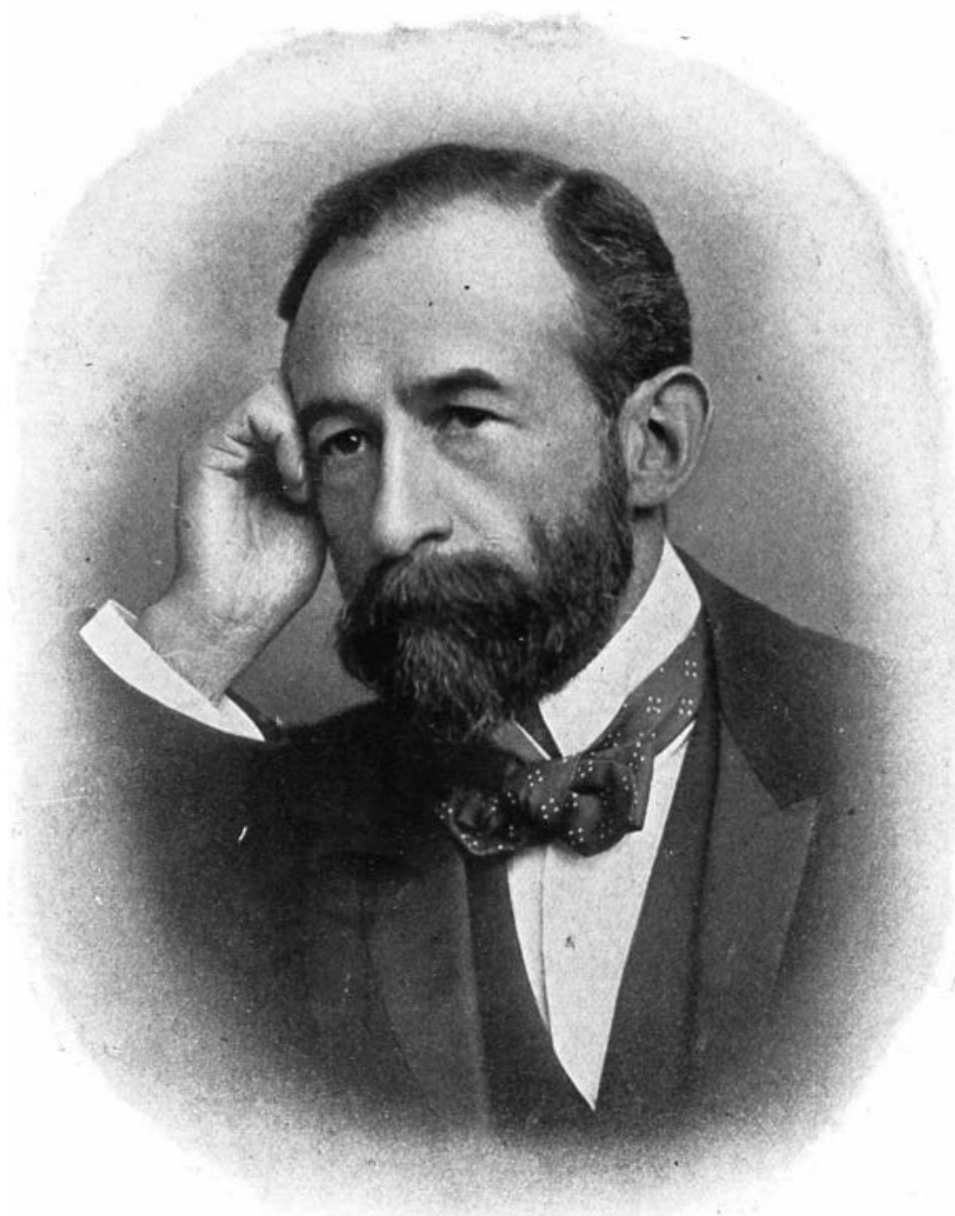

The late William Johnson Walshait.

To furt poge ti17, rol. ricii. 


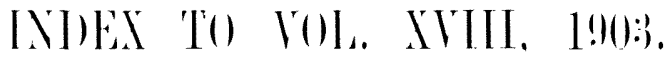

Abdomen (tumour of). case of tumour of meatus associated with (A. H. Cheatle)

Abercrombie (P. H.), a case of navus involving the urula, palate, fauces. tongue, and larynx . two cases of adhesion hetween the soft palate and the posterior
pharyngeal wall. the result of tertiary syphilis. operated on with ipoil results

L a case of hypertrophy of the lingual tonsil in a woman aged twent y-eight.

Alscess, ethmoidal (W. i

(intra-cranial). two cases (Vallette and Reverdin) .

(of cerelellum) after infection through labyrinth : death from

meningitis ; antopsy (A. Knapp) . . . . . 110

-.._ase following midile-ear disease (J. G. Andrew) $\quad .501$

- case of acute meningitis and (R. M. Simon) . . . 447

- - of otic origin (V. Gillot) . . . . . . 442

- operation; recovery (C'. Douglas) $\quad . \quad 109$

- otitic origin (Gaudier)

Jones)

of epiglottis: case with secondary involvement of cervical glands

(W. L. Culluert)

- of frontal sinus, exhilition of patient operated upon three times

for (M. Collier)

of hard palate and of septum nasi following left antral empyema

(Hunter. Toul) of septum. hilateral. with well-marked symptoms of septicamia

(W. L. Cullert)

. in che .

(retro-pharyngeal) in children (J. L. Morse).
(temporo-sphenoidal): demonstration of case after operation

(H. E. Jones)

Accessory sinuses: see Simuses (accessory).

Acoumetry in micro-millimetres (H. J. L. Struyschen) . . 3.5)

Adamkiewicz's cancroine curing some cases of cancer (A. Remanlt) $\quad$. 614

Adructor paralysis, hilateral, following tonsillotomy (V. Wyatt Win(riave)

$\begin{array}{lll}\text { Adractures of vocal cords, clonic contraction of (F. J. Steward) } & 312 \\ & . & 320\end{array}$

Adeno-carcinoma : case shown on February 5. 1900. probahly in reality an encothelioma (A. H. Cheatle)

Adenoid reafness. difficulties and insufficiency of stenosal theory of (D. Mr.Keown)

Adenoid prowths in chiliren (J. E. Schadle)

Adenoids: fatal case of secondary hamorrage four days after removal of adenoids (P. G. Gollsmith)

removal of, in cure of case of persistent superficial nawal hyperamia (V. Wyatt Wincrave) 
Adenoma of palate (G. King) . . . . . . . . . .

ADERMAN : the masto-squamosal suture (abstract) : . $3 \times 6$

Adhesion between the soft palate and the posterior pharyngeal wall, the result of tertiary syphilis (P. H. Abercrombie) il of phingn $\mathrm{H}^{\circ}$ (complete) of soft palate to posterior wall of pharynx $(H$. Adrenalin, use of, in oto-rhino-laryngology (V. Delsaix) $\quad . \quad$.

Air-passages, lodgment of a foreign hody in (R.A. Wilson) . . 44)

(upper), endotheliomata in (W. Jobson Horne) : $\quad .416$

Coffin) relation to diseases of gastro-intestinal tract (L. A.

ir-pressure, normal fluctuations of, in upper respiratory tract; lantern demonstration (Scanes Spicer)

Air (superheated compressed) in the therapentics of chronic otitis media (G. W. Hopkins)

Allen (S. W.). a probable myxofibroma of the nose (abstract)

ALTER (Francis), paraffin injection in a case of so-called saddle-nose (abstract)

American Laryngological, Rhinological and Otological Society : Ninth Annual Meeting (1903) . . . 492, 540,590, ti2

Amyloid degeneration in the larynx, causing stenosis (W. Courvoisier). lot

_ disease : case of chronic œdema of larynx (? amyloid) (J. Dundas Grant)

Anæsthetic chnice of, in short operations upon the throat and nose (J. H. Chaldecott)

Anatomical specimens, demonstration of (H. E. Jones) :

ANDREw (J. G.), case of cerebellar abscess following middle-ear clisease (abstract) .

Aneurysm (of aorta) : large aneurysm of arch of aorta shown by rarlioscopic examination in case of paralysis of left recurrent nerve ( $V$. Cheval)

of occipital artery. causing entotic mumur (Muck)

Ankylosis of left crico-arytænoid articulation (J. Donelan) of the stapes (Professor Denker)

Anosmia, case of (P. M.Bride)

Antrectomy, morphological value of supra-meatal spine and tache spongieuse (O. Lenoir)

Antrum (disease) and otitis media (C. G. Lee) double antral and frontal sinus disease: left side cured by radical operation; question of operating on right side (Hunter Tod) (left): empyema followed hy ahscess of hard palate and of septum nasi (Hunter Tod)

(mastoid) not involved in case of primary acute purulent inflammation of mastoid cells (J. Dunn) maxillary, empyema of. unusual case (P. G. Goldsmith)
antra (H. Tilley) (chronic) of both frontal sinuses and maxillary

tion of radical operations illustrating almost complete ohliterachronic empyema of hoth frontal sinuses and pration in atase of

\footnotetext{
Tilley) $\begin{aligned} & \text { serew perforator for (W. D. Haslam) } \\ & \text { technique of operations on (H. H. Curtis) } \\ & \text { transillumination of (C. Ziem) }\end{aligned}$ (Moure)
}

Successful operative opening for cholesteatoma (Dumias Grant)

Aphonia (functional) (H. Lamhert Lack) in a man with unusual symptoms (H. Lamhert Lack)

Appendicitis in relation to tonsillitis (Hans Weher). 
Artery (central) of retina : emholism of central artery of retina causing hilindness immediately after paraffin injection into nose (L. MI. Hurd) - (ccipital). entotic murmur due to aneurysm of (Muck)

Arthritis (rheumatoid) and pseudo-rheumatism of larynx (Mourut) . 202.3

Arytatnoid cartilage (right): infiltration of, ohscure lardaceons-looking variable (Sir F. Semon)

Arytimoids: swelling in case of double alductor paralysis (C. A. Parker)

Asthma, nasal treatment of (A. Francis) . . .

Atresia (congenital) of external anditory meatus with microtia. three

(ases (E. Jürgens) .
Attic.

... - successful operative opening for cholesteatoma (Dundas Grant). 84

Auditory apparatus, theory of cross-education as applied to (L. S. Somers)

Auditong arear cortioul lowalisution of (A. Camplell)

Aulitory nerve: see Nere (auditory).

Auricle, epithelioma, two ases shown after operation (C. (x. Lee) . די3

BABER (E. Cresswell), extensive fenestration of the anterior pillars of the fincess

- a case of oljective clicking timnitus

- a a itumour of the vestibule of the nose microscopic section

Baccilli (" acid-fast" "). microscopical examination for, in discharge in one hundred cases of middle-ear suppuration (Wyatt Wingrave)

Bacteriological examination of four cases of acute septic inflammation of throat (P. R. W. de Santi) .

Bacteriology, alstratct of literature on . . . .

Ballance (C. A.), discussion on tuberculosis of ear, nose, and nasopharynx

Ballance (H. A.) and STEwart (Purves), remarks on the operative treatment of chronic facial palsy of peripheral origin (abstract) . 501

Baliencer (W. L.), a foreign lody removed from the nose . . 4.94

BARK (John), al case of cancer of the cesophagus . 306

- - caseous rhinitis. . . . . 619, totri

BAron (Barclay J.), (ase of naso-pharyngeal malignant disease . Et

Belleve : a case of tuber(ulous tumour on the posterior part of septum nasi (ahstract)

BEzoud's mastoiditis : see Mustoiditis (Bezold's).

Birds (diphtheria in): non-identity of human and avian diphtheria (C. Guórin)

BLAkE (C. J.), on tension anomalies of the sound-transmitting apparatus of the middle ear (athstract) .

Blindness from embolism of central artery of retina immediately following paraftio injection into nose (L. II. Hurl

Bolt cammla in cases of difficulty in " décamulement" (Cuno).

Bone: extensive destruction in hereditary syphilis and searlittina: demonstration of case after operation (H. E. Jones)

- (temporal) : see Temporal bonc.

Bone-stopping : iodoform bone-stenpinar (Mosetir-Moorhof) . . :3i:

Bones of nose: see Nose (homes of ).

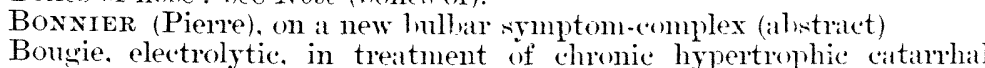
deafness (A. B. Duel)

Eustachian. use and abuse of (M. A. (roldstein)

Brain (diseases, pyogenic): (asses associated with o" (ansed ly acute or chronic nasal suppuration (T. Huhbard

Braisun (William C.). at case of teratoma of the ear 
BreYre (C.). a case of otitic pywmia; recovery (ahstract) . . . 334

Bright's disease and pharyngitis sicea (Joal) . . 101

BrindeL and Moure (E.J.), ultimate results of paraffin injections into the nasal mucosa in seventy cases of typical ozanatous atrophic rhinitis

British Laryngological, Rhinological, and Otological Ássociation, Annual Dinner

- Annual General Meeting . proceedings

British Medical Association : Ammual Meeting. Section of Laryngolory and Otology . 48, 461,513,565, 640

Broeckaert (J.). contribution to the stuly of acquired and congenital perforation of the soft palate (abstract)

Bronchocele, immobility of left rocal cord attributable to $(\dot{J}$. Dundas Grant)

Bronner (Adolph), drawings of two cases of large retro-auricular opening (after operation for cholesteatoma) treated by paraffin injections .

a drawing. with notes, of a case of suppurative ethmoiditis and frontal sinusitis after radical operation for nasal polypi a specimen of columnar-celled carcinoma of the naso-pharynx from a man aged sixty-three. discussion on the technique of operations on the temporal hone in suppurative middle-ear disease on the local use of formalin in the treatment of nasial polypi before and after operation on the same by the usual methods (reply)

Brown : see Price-Brourit.

BRüHL (G.), an anatomical method of demonstrating the accessory cavities of the nose (abstract). on the duplicity of the accessory sinuses of the nose (alistract) "Atlas and epitome of otology," by Gustar Bribl, with the collaboration of Professor A. Politzer. Authoriser translation from the German. Edited by S. MacCuen Smith (review)

Bulb of internal jugular vein, operative exposure of (Piffi)

Bulbar symptom-complex (new) (P. Bomnier)

Burt (A. Hamilton), a case of epithelioma of tongue in a single woman aged twenty-four

- a case of exophthatmic groitre

Burlis (H. T.). a clinical lecture on my unsuccessful operations for cancer of the tongue, and on the early diagnosis of the disease (abstract) .

an account of eight cases of "pressure-pouch" of the resophagus removed by operation (abstract)

Butro (H. Hayle), hypertrophy of lymphoir ring of pharynx and its surgical treatment (ahstract)

CaIRNS (D. Lonis), on the treatment of diphtheria by intra-renous injection of antidiphtheritic serum (abstract) . . . 447

CAMPBELL (A.), cortical localisation of the anditory areat $\quad 339,354$

Cancer of larynx : ase cured by X rays (W. Scheppegrell) : 70

- results of treatment hy X rays (D. B. Delavan). 51. 276

- surgical treatment (E. J. Moure) . . Sts

- of cosophagus, case of (J. Bark) $\quad . \quad 504$

without olistruction (J. G. Emannel) : $\quad . \quad 10.5$

- of tongue, early diagnosis (H. T. Butlin) . : . : 274

unsuccessful operations (H. T. Butlin) $\quad: \quad 5$

- some cases cured by Alamkiewicz's cancroine (A. Renault) . 614

Cancroine (Adamkiewicz's), curing some cases of cancer (A. Renault) . 614

Camnula for frontal sinus (W. J. C. Nourse) 2918, 418 
Gammula for sphemuidal simus (W. J C Nourse) for washing out attic and simus (Léry) $\quad . \quad 5.58$

Cammula: fixed tubes and bolt camnulas for cases of difficulty in " déramulement" (Cuno)

Carcinoma of epipharyox (H. W. $\dot{\mathrm{L}}$ (jel)

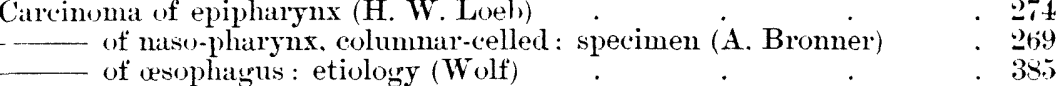

Carnegie Dickson (W. E.). expectoration of a tooth thirteen months after inhalation into the lung (abstract) . . . $\quad .39$

CAstex (A.). causes of deaf-mutism . . . . . . 348

Catarrh of middle ear, chronic, casts of upper and lower jaw from case of (P. Nelsom)

Cerehellum, abscess of. after infection through labyrinth; death from meningitis; autopsy (A. Knapp)

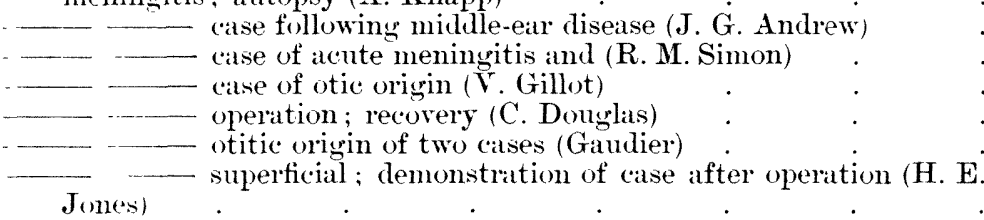

Cerehral nerves: see Nerves (cerebral).

Cervical glands: see Glomds (cervical).

CHALDEcotT (J. H.), the choice of an anasthetic for short operations upon the throat and nose (abstract)

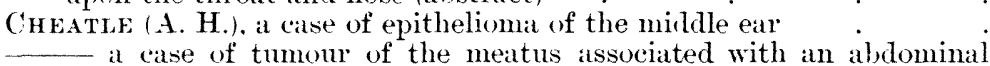
tumour. discussion on tuberculosis of ear, nose, and naso-pharyix
a cass of tuberculosis of the midale ear (secondary)
specimens of tuberculosis of the temporal bone
temporal hones remored from patients who died of tuberculons
meningitis.

- - a case which was shown on Fehruary 5, 1900, as an adenocarcinoma, probally in reality an endothelioma, with section . 19

CHFvi (V.). paralysis of the left recurrent nerve; large aneurysm of the arch of the aurta; radiography (ahstract)

CHEVALIER and GAUDIER : two cases of thyroid tumours at the base of the tongue (abstract)

CHInde (C. P.). discussion on operative treatment of malignant disease of laugnx .

Cliscussion on local use of formalin in treatment of nasial polypi

Children. adenoid growths in (J. E. Schadle)

Choand in atult human skulls, dimensions, form, direction, and symmetry of (S. Citelli) .

Cholesteatoma, cystic, from the left supa-tonsillai fossa (V. Wyatt Wingrave) .

of attic and antrum, successful treatment by operative opening (J. Dundits Grant) . opening after operation for cholesteatoma treated with paraffin injections (A. Bronner) . . . . pan remored hy operation, facial paralysis rapidly subsiding (J. Diundas Grint)

Christiani : on thyroid grafts.

Christrasses (Hans B.). lupus vulgaris of the respiratory muenus memlnanes as it oceurs and is treated in the Finsen Light Institute of Copenhagen

Citelur (S.). the dimensions, form, direction, and symmetry of the choanit in adult human skulls (abistract) 
Clonic spasm of muscles of palate and pharynx causing entotic tinnitus (L. H. Pegler)

- spasm of soft palate causing objective noises in pharynx (L. H. Pecrlè')

$P A B$

CoAkLeY (Cornelius G.), an unusual case of frontal sinusitis in which there was absence of the septum

Coen (Rafael), the progress in the cure of defects of speech

CofFIN (L. A.), the relations of the upper air-passages to diseases of the gastro-intestinal tract

Collier (Mayo), a case of malionant wrowth of the larynx a case of myxo-sarcoma in the nasal cavity - case of extreme displacement of the nose . . . . . $\quad .24$

- case of wandering rash on the tongue

- on nasal obstruction, and deformities of the upper jaw, teeth, and palate (abstract) a case of empyema of frontal sinus .

a man aged fifty who had been operated on three times $f\left(c^{\circ}\right.$ frontal sinus abscess

Compaired (Célestin), neurasthenia of intra-nasal origin (abstract)

Congress, Fourteenth International Medical, at Madrid: Section of Laryngology and Rhinology .

-

- Section of Otology .

Conservatism in treatment of acute mastoiditis (S. S. Snow)

Contagion in acute middle-ear disease (Kluge)

Contagiousness of otitis media (acute) (L. Wolff)

Copenhagen: lupus vulyaris of respiratory mucous membranes as it occurs and is treated in Finsen Light Institute of Copenhatgen (H. B. Christiansen)

Cord (vocal) : see Vocal cord.

Corrigendum

Cortical localisation of auditory area (A. Camphell) .

Coryza, atrophic: is it an autonomous affection? (E. J. Moure) . 3103

CoUrvoisier (W.), on stenosis due to amyloid degeneration in the larynx (abstract) .

Cricoid cartilage, papilloma (large) from posterior aspect of ; microscopic specimen (R. Lake)

Crocket (A. P.), chronic suppuration of accessory carities of the nose (abstract) .

Cross-education: theory of cross-education as applied to aturlitory apparatus (L. S. Somers)

Cromp, clinical lecture upon the treatment of (Lorthioir)

Culbert (W. L.), a case of bilateral abscess of the septum with wellmarked symptoms of septicamia

_ a case of epiglottic alscess with secondary involvement of the cervical glands

Cumberbatch (A. E.). discussion on tulierculosis of ear, nose, and naso-pharynx

Cuno: fixed tubes and holt camnula for cases of difficulty in "decamulement" (abstract)

Curtis (H. Holbrook), the technique of maxillary antrum operations :

Cushina (Harvey), the taste-fibres and their independence of nervis trigeminus (alistract)

(yst (mucoid) of left middle turhinal (G. T. Ross)

\section{Co epiglottis (H. FitzGerald Powell)} of rentricle of larynx, opened when operating on a case of malignant discase (H. Lambert Larek). . . (supra-nasal) in an infant (V. Wyatt Wingrave)

Cyto-diagnosis, catse of otitic meningitis with (Ledoux)

Davis (H. J.), a case of swelling of the right side of the larynx (for diannosis). 


\section{Index.}

Deaf : method of dealing with and developing the residual hearing power and speech of the deaf (J. K. Love)

Deaf-mutes: respiration during speech (H. Gutzmann)

Deaf-mutism (causes of) (A. Castex)

- (E. Schmiegrelow)

Deafness (arlenoid), difficulties and insufficiency of stenosal theory of (D. McKeown)

amelioration of hearing trombles following suppurative otitis (B.

Gomperz) .

case due to myxcedema (J. Dumdas Grant)

- catarrhal, chronic hypertrophic, possililities and limitations of

electrolytic bougie in treatment (A. B. Duel)

(chronic) of middle ear, use of ozone in (G. Stoker)

due to myxodema (J. Dumdas Grant)
- quinine-deafness and its prevention (A. Cheatle)
scientific treatment (Marage)

scientific treatment (Marage)

--.- see also Nerre-deafuess.

DEANescy (E.), portions of temporal and adjoining hones (right sirle), with malignant growth the size of a walnut springing from the tympanum and invading the under side of the temporo-sphenoidal lobe, from a man aged forty-four

Décamulement. fixerl tubes and holt cannulx in ases of difficulty in (Cuno)

Defects of speech, progress in cure of (R. Coen)

Deflection: septotome for use in Moure's and other operations for deflection (L. H. Pegler)

Deformities of the mpper jaw, teeth, and patate in connection with matsal ohistruction (Mayo Collier)

(nasil) : case of nasal deformity (W. R. H. Stewart)
Deravan (D. B.). on results of treatment of laryngeal cancer by X rays (a)stract).

results of treatment of laryngeal cancer by means of the $\mathrm{X}$ rays (alistract).

Dexsavx (V.), on the employment of adrenalin in oto-rhino-laryngrology (abstract).

- discussion on the technique of operations on the temporal lume in suppurative middle-ear disease preliminary note on the treatment of lupus of the upper respinatory tract liy radium (abstract)

DENCH (Edward B.), the technique of the radical operation for otitis media suppurativa chronica.

DENkER (Professor), ankylosis of the stapes (translated and alnidged hy Dr. Dumlas Grant and Dr. Stolte)

Davorks and Moures. on the employment of high-frequency currents in oto-latyngology (abstract).

Diamosis, cases for : anosmia. case of (P. McBride) aural case for diagnosis (L. H. Peglev) dysphagia of six months duration, probally pharyngeal epithelioma (J. Dunklas (rrant)

\footnotetext{
- wowth on left vocal con (P. de Santi) . swelling of right side of larynx (H. G. Davis)
see also Cyto-diagnosis.

see also Cyto-diagnosis.
Dieu, tertiary lesions in the naso-pharynx (abstract).

Diphtheria. dinical lecture upon the treatment of (Lorthioir) non-identity of human and avian diphtheria (C. Guérin)

treatment of, hy intra-renous injection of antidiphtheritic serum

(D. L. Cairns) . . . . . . . . . . .
}

Disease, histology of tonsils in relation to (J. L. Goodale) $\quad . \quad$.

Diseases: "High-frequency currents in the treatment of some diseares." (Chisholm Williams : review). 
Displacement. extreme, of nose (Mayo Collier)

Donelan (James), pedunculated laryngeal growth, probably dating from birth. in a boy aged fifteen

exhibition of specimen of large naso-pharyngeal fibro-myxoma with prolongations extending to anterior nares

case of ankylosis of left crico-arytanoid articulation in a woman aged twenty-three

- a case of perforation of the nasal septum; ?trauma or syphilis . a case of pharyngeal and laryngeal lesions in a woman aged twenty-eight - naso-pharyngeal fibroma cured by means of galvano-cautery puncture, by Dr. Urbano Melzi ; translated by Dr. James Donelan a case of subglottic thickening of right vocal cord in a man aged fifty-seven .

Dovglas (Claude), abscess in the cerehellum; operation; recovery (abstract) .

Dowling (J. Iremey), the ear complications of la grippe (abstract)
DuEL (Arthur B.), the possibilities and limitations of the electrolytic

DuEL (Arthur B.), the possibilities and limitations of the electrolytic
bougie in the treatment of chronic hypertrophic catarrhal deafness.

Duns (J.). the inferior occipital plate of the mastuid, with especial reference to Bezold's mastoiditis (abstract)

- a case of primary acute purulent inflammation of mastoid cells. involving neither middle ear nor the mastoid antrum (abstract)

DU POND : a case of tracheal ozæna, causing dyspnoea (alistract)

DURAND (A.) and JACQUES (P.). the choice of operation in chronic fronto-ethmoidal sinusitis (abstract)

Dysphasia (increasing) of six months duration. prohably pharyngeal epithelioma ; case for diagnosis (J. Dundas Grant)

Dyspncea caused by tracheal ozæna (Dupond)

Ear, abnormalities of : see Tragus (accessory). abstracts of literature 53, 108, 166ti, 2023, 276, 334, 386, 440,501,557.

accessory cavities of. diagnosis and treatment of tuberculous

disease in (W. Milligan)

disease of, without perforation of membrane, in case of suppuration hehind mastoid and in posterior fossa (W. Permewan)

- diseases: "A text-book of the diseases of the ear for students and

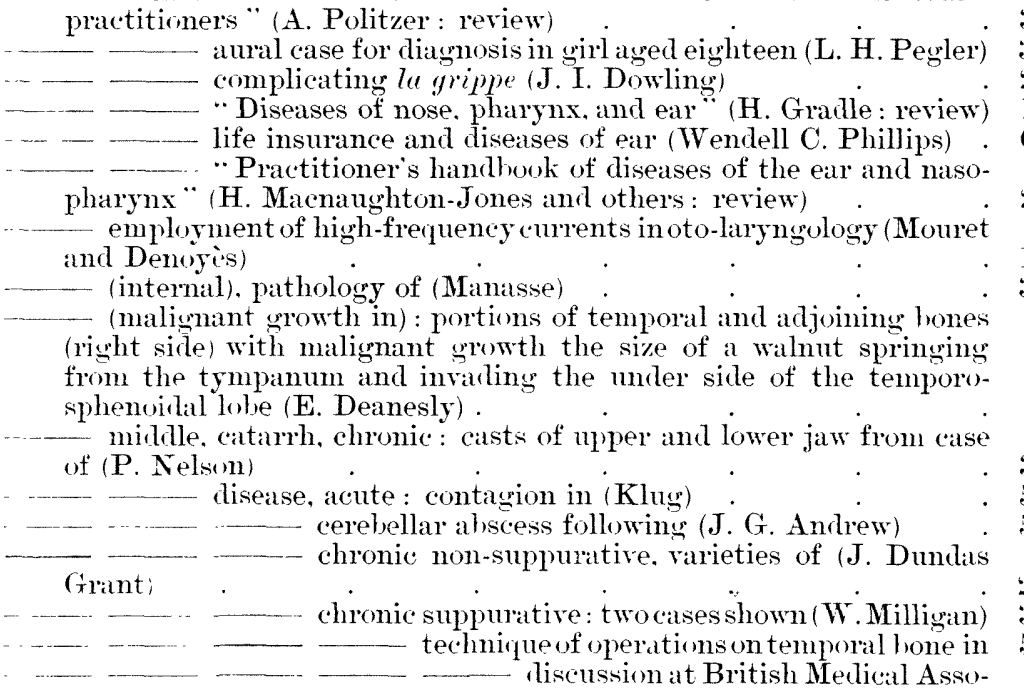




\section{Index.}

Ear, middle, epithelioma of (A. H. Cheitle) . inflammation. acute: question of early treatment to prerent the more seriuus complications (E. L. Meierhof) malignant growth of (W. Permewan). . . 363

ozone in chronic middle-ear deafness (G. Stoker) . 111

purulent inflammation (primary acute) of mastoid cells not involving (J. Dunn) suppuration. acute. treatment of (W. P. Phillips)

- microscopical examination of the discharse in one

hundred cases of middle-ear suppuration, with an analysis of the results, having special reference to the presence of tulercle and "acid-fast" hacilli (V. Wyatt Wingrave)

- suppuration with thromhosis of cavernous sinus ( $F$. Schiffers) tension anomalies of sound-transmitting apparatus of (C. J. Blake) - - tuberculosis of -
Milligan)
tuherculons disease of : diagnosisgend treatment (W. operations on ; after-treatment (Marcel Lermoyez)
retro-auricular opening (large) (after operation for cholesteatoma) treated hy paraffin injections (A. Bronner)

sequestrum comprising internal auditory meatus, superior and posterior semicircular canals. and greater part of the restibule

(shown hy H. E. Jones)

teratoma of (W. C. Braislin)

- tuherculosis of. bibliography discussion on discussion (Urluan Pritchard, C. A. Ballance, A. E.

Cumberbatch, A. L. Whitehead, Hugh Jomes, A. Cheatle) A 154-160 tubereulosis (primary) followed by mastoiditis : report of four cases (M. A. Goldstein) tuberculous disease of ear (W. Milligan) . . . 196

-
-

- Post-aural operation.

Ear and throat clinic at Rostock, usual methods of treatment and cperation in (O. Koerner)

Edelmann's $\mathrm{C}$ and $\mathrm{G}$ tuning-forks: ohjective uniform measure of hearing as supplied by amplitude of viluation of (Professor Ostmann) . 5.

Education: see Cross-education.

- (medical) : position of laryngology and otology in medical students' curriculum (P. Watson Williams)

Electricity (medical): " Hirrh-frequency currents in the treatment of some diseases" (Chisholm Williams: review)

Electrolytic bougie in treatment of chronic hypertrophic catarrhal deafness (A. B. Duel)

Eulis (H. Bert), some unusual mastoid cases

Elsworth (R. C.), discussion on the technique of operations on the temporal hone in suppurative middle-ear disease.

EMANUEL (J. G.). cancer of the cesophagus without obstruction (ahstract)

Embolism of central artery of retina causing blindness immediately after paraffin injection into nose (L. M. Hurd)

Empyema (chronic) of both frontal sinuses and maxillary antra (H. Tilley) 367

- - of sphenoidal sinus; opened (E. B. Waggett) . . 379

— of frontal sinus (MI. Collier) _. . 3 . 3 
Empyema (of left antrum), followed by aloscess of hard palate and of septum nasi (Hunter Tod)

P IF 3is

- - of maxillary antrum, unusual case (P. G. Goldsmith) . 625, 64.5 of right maxillary antrum and both frontal sinuses with necrosis of the orbital wall (Mome) . . . . of masal accessory cavities in case of osteomyelitis of skull (A. Knapp)

Encephalitis in connection with otitis media: three cases (Voss)

Endothelioma: probable case of endothelioma shown on February 5. 1900. as an adeno-carcinoma (A. H. Cheatle)

Endotheliomata in upper air-passaures (W. Jobson Horne)

Entotic murmur due to aneurysm of occipital artery (Muck) . $\quad 44 i$

Epiglottis, abscess : case with secondary involvement of cervical glinds (W. L. Culbert) cyst of (H. FitzGerald Powell) destroyed, with new growth occupying glottis (W. Jobson Horne) epitheliomis of the epiglottis (advanced and inoperable) with secondlary infection of the cervical ylands; illustration of the relief ohtained hy removal by " morcellement " of primary growth through mouth (Herbert Tilley)

- _ cumma of (P. de Santi) removal of for tuberculous disease (Richard $\dot{\mathrm{I}}$ (ake)

Epilepsy simulated in nasal vertigo (E. Woakes)

Epipharynx. carcinoma of (H. W. Loeb)

Epistaxis (persistent) (C. A. Parker)

Epitheliuma of aturicle: two cases shown after operation (C. G. Lee) of epiglottis (advanced and inoperable) with secondary infection of cervical glands: illustration of relief obtained by " morcellement" of primary growth through mouth (Herbert Tilley) of external auditory meatus (J. Dundas Grant) specimen ( $\mathrm{V}$. Wyatt Wingrave) of larynx (A. Thorne)

case of disease of larynx. probably epithelioma $(J$. Dundas Grant two cases remaining well two years after operation

(thynotomy) (E. S. Yonge) of middle ear (A. H. Cheatle)

of nostril. section of (V. Wyatt Wingrave) of pharynx, probable. in a case of increasing dysphagiat of six months duration (J. Dundas Grant) of pharynx and tonsil; specimen (V. Wyatt Wingrave)

- of pinna: two specimens and micruscopic sections (E. M. Stockdille)

dides or symmetrical swellings of gum at posterior ends of alveolar
lat horder (W. G. Spencer)

Escat : treatment of chronic hypertrophic pharyngitis by scarification (abstract)

Ethmoid : see Simusitis (fronto-ethmoidal).

Ethmoidal aloscess (W. Lamb)

Ethmojditis : pathology reconsidered (E. Woakes) - (suppurative) and frontal sinusitis after radical operation for nasal polypi (A. Bronner) . . . . . .

Eulenstein (H.). toxamia from suppuration in the temporal hone (alistract) .

Eustachian hongie, use and aluse of (M. A. Goldstein) tuhe (right). malignant disease in neighbourhood of (E. B. Waggett)

Fxploritory puncture: see Puncture (exploratory). 


\section{Index.}

Exposure and irrigation of bulb of internal jugular vein in operation for septic sinus thrombosis (Zoufal)

Eye : oculo-orlitary complications of sinusitis (F. de Lapersonne) . .

transillumination of (C. Ziem) . . . . . $\quad 284$

Face, lupus of (?) (D. Vinrace)

Facial nerve: see Nerce (facial).

FAGGE (C. H.), discussion on tuberculosis of ear, nose, and naso-pharynx

Farqu specimens of tuberculous disease of the middle ear Department of Eye, Ear, and Throat Infirmary at Edinburgh . $\quad 56$

Fances: abstracts of literature on . $\quad$. $\quad 51,500,556,609$

- - fenestration (extensive) of anterior pillars of fauces (E. C. Baber) 31

- involved in case of nævus (P. H. Alercrombie) . 25 - lupus of (W. H. Kelson) . - pillar of (anterior), hereditary specific perforation of ( $J$. Dumdas Grant) ucerating growth of left tonsil. side of tongnue, and anterior fancial pillar (H. FitzGerald Powell)

Fenestration (extensive) of the anterior pillars of the fauces (E. C. Baher) Fibro-lipoma of larynx. enormous (P. de Santi)

Filiroma of naso-pharynx (J. Dundas Grant) cured by means of galvano-cautery puncture (U. Melzi) specimen ( $V$. W yatt Wingrave) (vascular) finally removed by a combined operation through hard and soft palate. with extensive removal of anterior wall of left supra-maxillary bone (Herbert Tilley)

Filro-myxoma of naso-pharynx (large), with prolongations extending to anterior nares (J. Donelan)

Finsen Light Institute. Copenhagen: lupus vulgaris of respiratory mucous membrame, as it oceurs and is treated in (Hans B. Christiansen)

Fistula of larrnx (W. H Kelson).

Fixation of right vocal cord, case of (W. Johison Horne) $\quad . \quad$.

Fontoynont and Jourdran : streptococeal glossitis and stomatitis in Madagascar (abstract)

Forceps : new design for sphenoidal cutting forceps (P. Watson Williams)

Foreign body in air-passages, lodgment of (R. A. Wilson) . . 440 in naso-pharynx (R. Lake) . . . . . 102

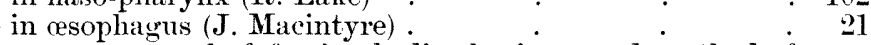

using Röntgen rays (G. Hamilton)

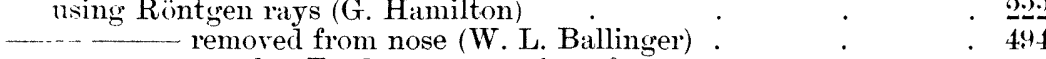

- - - see also Tooth (expectoration of).

Formalin : local use in treatment of nasal polypi (A. Bronner) . . 660

Forshaw (C. F.). case of tumour of the superior maxilla (abstract) . $_{160}$

Fossa. left supra-tonsillar, cystic cholesteatoma from (V. Wyatt Win(grave)

Francis (Alexander), the nasal treatment of asthma (abstract) $\quad$. 162

Frecdenthal (W.), etiology of ozana . 30.2

Friedlinder's pneumo-hacillus, a cause of sore throat (Nicolle and Hebert) 5.3

GALAND : sublabial rhinotomy (abstract) . $\quad . \quad .163$

Galloway (D. J.), on otomycosis of the Malay archipelago ${ }_{\text {. }}$.

Galvano-cautery puncture, naso-pharyngeal fibroma cured by means of (C. Melzi) .

Gastro-intestinal tract (diseases of), relations of upper air-patsanges to (L. A. Coffin)

GACDIER : two cases of cerehellatr alscess of otitic origin (abstract) . 441 tond Chevalier : two cases of thyroid tumour at the base of the tongue (abstract) 
Gillow (V.). cerebellar ahscess of otic minin (abstract)

Glands (ceruminous) from the cartilaginous portion of external auditory meatus (V. Wyatt Wingrave) . - (cervical), secondary infection of, in case of advanced and inoperable epithelioma of the epiglottis (Herbert Tilley) . Culbert) (lymphatic) : see Lymphatic glands. (tuberculous). perforation of asophagus by (C. Riviere)

Glossitis (streptococeal) in Marlagascar (Fontoynont and Jomrdran

Glottis occupied by new growth in patient with destruction of epiglottis (W. Jobson Horne) .

Gucck (Professor T.), discussion on the operative treatment of malimant disease of the larynx (introductory remarks)

$\ldots$ (reply) - discussion on the technique of operations on the temporal home in suppurative midale-ear disease

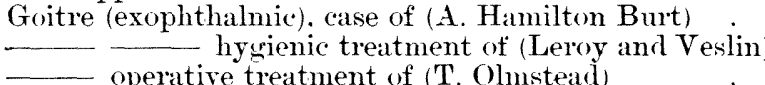

Goldsmirh (P. G.), fatal case of secondary hamomatige four diays after removal of adenoids (abstract)

_- an unusual case of empyema of the maxillary antrum notes of an unusual case of empyema of the maxillary antrum

Golostern (M. A.), primary tuherculosis of the ear followed hy mastoiditis : report of four cases

the Eustachian hougie: its use and abuse
Gomperz (B.). on the amelioration of the troubles of hearing following suppurative otitis (abstract)

Gonococeus causing mastoiditis (C. Trow)

Goonale (J. L.). histology of the tomsils in their relation to risease (discussion on the mpper respiratory tract as a source of systemic infection)

Goris (C.), technique of the surgical treatment of chronic sphenoidal sinusitis (abstract) .

Gradue (H.). "Diseases of the nose, pharynx, and ear" (review)

Grafting: demonstration of cases of complete post-aural operation with and without grafting $(H$. E. Jones)

Grafts (thyroid) (Christiani)

GRANT (J. Dundas), case of paralysis of the abductors of the vocal cords and of the palatal muscles, and slight paresis of the tongue, in a man agred twenty-five a case of cholesteatoma of attic and antrum, with good result by operative opening of these parts, with preservation of the ossicles, memhrana tensa, and cholesteatoma matrix

- a case of comparative hemianasthesia in a young fenale. with subjective nasal obstruction on the affected side . a case of increasing dysphacria of six months duration in i middle-aged man (for diagnosis); probably pharyngeal epitheliomit . _.. discussion on tuberculosis of ear. nose. and naso-pharynx

- a case of cholesteatoma removed by operation; facial paralysis rapidly subsiding

- $\ldots$ the varieties of chronic non-suppurative disease of the middle ear case of chronic laryngitis with interarytanoid pseudo-pachydermic swelling. probably due to purulent rhinitis

_ case of hereditary specific perforation of the anterior pillar of the fauces

- a case of deafness due to myxedema
- a case of immobility of the left vocal cord, attributable to bron-
chocele, in a young woman; resection ; extirpation of the isthmus chocele, in a young woman; resection ; extirpation of the isthnms
and left lobe 
Grant (J. Dundas). a case of paresis of both recurrent laryngeals and left sympathetic in a middle-aged woman

- a case of disease of the larynx of twelve months' duration. probably epithelioma. in a man aged fifty

- a case of chronic laryngitis, with papillated thickening of rocal cord and chronic rhinitis

- translation and alridgment of Professor Denker's paper on ankylusis of the stapes discussion on operative treatment of malimant disease of larynx

- on the technique of operations on the temporal bone

in suppurative middle-ear disease

a case of deafness due to myxcedema: complete recovery of hearing

a case of epithelioma of the external anditory meatus .

- a case of filiroma in naso-pharynx and Nourse (Chichele). retrospect of otology, 1902

Granuloma (tuherculous) of larynx (V. Wyatt Wingrave)

Grippe (La): see Influenza.

Growth (adenoid): see Adenoid grouths.

in post-natsal space appearing helow soft palate in infant $(H$.

FitzGerald Powell) .

- (malignant). walnut-sized, shown with portions of temporal and adjoining bones (right side) springing from tympanum and invading under side of temporo-sphenoidal lobe (E. Deanesly)

- (malignant) of larynx (Mayo Collier)

(new) involving left inferior turbinate and septum (R. Lake)

(W. Johson Horne)

Nourse) of nose, external. presenting umsual structure $1 C^{\circ}$. Nemoved from posterior extremity of right inferior. turlinate body (R. Lake) of larynx (V. Wyatt Wingrave) in a woman (W. H. Kelson). - (pedunculated) (James Domelin) on left rocal cord : case for diagnosis (shown hy P. de Santi) (ulcerating) of left tonsil. side of tongue, and anterior faucial pillar (H. FitzGerald Powell) .

GRônWLD (L.). "Atlas and epitome of diseases of the mouth. pharynx. and nose." (Second edition reviserl and enlarged : anthorised translation from the German; edited, with additions, hy James E. New(comb: review)

Guiris (C.). on the non-identity of human and avian diphtheria

Gum: swellings (symmetrical) at posterior ends of alveolar horder (epulides) (W. G. Spencer)

Gumma of epiglottis (P. de Santi).

of larynx, sequel of case (C. Nourse) of nasal septum (L. H. Pegler)

Gutzman (H.), respiration of deaf mutes during speech

Hæmorhage (secondary) : fatal case four days after remoral of adenoids (P. G. Goldsmith)

Hæmostatic: pengawar-djambi as hæmostatic agent in nasal operations (Lubet Barbon)

Hat.L (F. de Havilland), discussion on the upper respiratory tract as a source of systemic infection : introductory remarks

Hamilton (George). removal of foreign hodies from the cesophayns liy an improved method of using the Rintuen rays (abstract)

Hamilton (H. D.), ocelusion of right posterior nares (alstract)
HARTManN (Arthur). introductory remarks in the discussion on the technique of operations on the temporal bone in suppurative middleear disease. 
HASLAB (IV. D.), an improved screw maxillary antrum perforator

Hay ferer, experiments on nature and specific treatment of (Sir F. Semon) 447 import of salivary and nasal secretions in (D. B. Kyle)

Hearing : amelioration of hearing troubles following suppurative otitis (B. Gomperz)

objective uniform measure of hearing as supplied by amplitude of vibration of Edelmann's $\mathrm{C}$ and $\mathrm{G}$ tuning-forks (Prof. Ostmann)

recovery, complete, in case of deafness due to myxcedema $(\vec{J}$. Dundas Grant)

Hearing power (residual) of the deaf, method of dealing with and developing (J. K. Love)

Hebert and Nicolte : sore throat due to the pneminolacillus of Friedlinder

Hemianæsthesia (comparative) with suljective nasal obstruction on the affected side (J. Dundas Grant)

Herpes, question of, in a case of recurring ulceration of the pharymx and larynx (E. Furniss Potter)

High-frequency currents, employment of, in oto-laryngology (Mouret and

Denoyès) in the treatment of some diseases (Chisholm Williams: review)

HöDEuroser (C.), primary sarcoma of the larynx (abstract)

Hopkiss (G. W.), on superheated compressed air in the therapentics of chronic catarrhal otitis mediat .

Horne (W. Jolson), patient with a new growth occupying the glottis.

and with destruction of the epiglottis ${ }^{2}$ the clinical diagnosis and surgical treatment of tuberculosis of the temporal hone. considered with reference to the pathology and morlid anatomy of the disease

reply to discussion on tuherculosis of ear, nose, and naso-pharynx primary tuberculosis of the ear; the specimen from a case of general miliary tuberculosis with primary focus in the temporal hone a case illustrating the earlier changes resulting from injury to nasal septum

macroscopic and microscopic preparations illustrating endotheliomata in the upper air-passages discussion on operative treatment of malignant disease of larynx on the technique of operations on the temporal lone in uppurative mirldle-ear disease

fon the upper respiratory tract as a source of systemic infection ; introductory remarks

$$
\text { (reply) }
$$

the clinical diagnosis and surgical treatment of tuberculosis of the temporal hone (abstract) . a case of papilloma of the vestibule of the nose

discussion on local use of formalin in treatment of nasal polypi .

Hinsbera (V.). suppurations in the lahyrinth (abstract)

HubBard (Thomas), cases of pyogenic brain diseases associated with or: caused by acute or chronic nasal suppuration

Htrd (L. M.), a case of paraffin injection into the nose followed immediately by blindness from emholism of the central artery of the retina (abstract)

Hutchison (Arthur J.), on the treatment of syphilitic disease of the mucous memliane of the mouth and throat. By Anton Lieven: translated hy Arthur J. Hutchison

Hycrienic treatment of exophthalmic poitre (Leroy and Veslin)
Hyperamia of nose, persistent, superficial, cured by removal of adenoids (V. Wyatt Wingrave)

Hyperostosis, large. of left amal meatus removed $(\mathrm{H}$. Tilley) .

Hypertrophy of lingual tonsil (P. H. Alercromlie) of lymphoid ring of the pharynx (H. H. Butto)

Hyposlossal nerve : see $N^{\prime}{ }^{\prime} v^{\prime}$ (hyposlossal). 
Implantation of facial to hypoglossal nerve (Körte) . . . 4t6

Infant : growth in post-nasal space appearing below soft palate in infant (H. FitzGerald Powell)

Infection : respiratory tract (upper) as source of systemic infection; dis('ussion at British Medical Association Anmual Meeting (1906) 56.5-590)

- introductory remirks (F. de Havilland Hall) .

- - W. Jobson Horme .

- - pathology (F. Poynton) . . . . 581

- part played by nose and naso-pharynx as source of

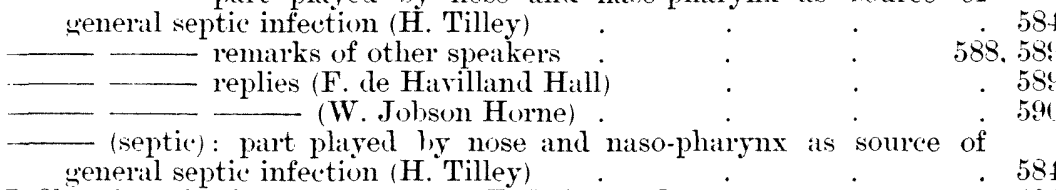

Infiltration of soft palate (: cause) (F. J. Steward) . . . 434

of pharyx and post-nasal space ( $\mathrm{H}$. FitzGerald Powell)
Inflammation of throat, acute septic ; four cases with hacteriological examination of each (P. R. W. de Santi)

- (primary, acute, purulent) of mastoid cells. involving neither midlle ear nor mastoid antrum (J. Dumn)

Influenza : ear complications of " la grippe " (J. I. Dowling) · $\quad \cdot \frac{2}{2} ;$

Infundibular probe, new form of (W.J. C. Nourse) . .

Injury: earlier changes in nasal septum resulting from injury (W. Jolison Horne)

Instruments, new exhilition of (C. Jackson)

Insuction of alat nasi; treatment (K. M. Menzel

Insurance (life) : see Life insurance.

Interarytanoid pseudo-pachydermic swelling. with chronic larynuitis, probably due to purulent rhinitis (J. Dundas Grant)

Interarytienoid region : swelling (large) of mucous membrane in so-called interarytienoil pachydermia (H. Tilley)

Intermational Medical Congress (Section of Laryngology and Rhinology). 301); (Section of Otology)

384

Intra-nasal pressure cansinaticdoulourenx and cranial neumaluia (S. F. Snow) 6430

Intrat-renous injection of antidiphtheritic serum in diphtheria (D. L. Cairns) 44

Iodoform bone-stopping (Mosetig-Moorhof).

Irrigition, after exposure of hull, of internal jugular vein in operation for septic sinus-thromlosis (Zoufal)

JAcksos (Chevalier), notes on the radical mastoid operation (alistract) . 389 - exhibition of new instruments . 492. 493

JACQues (P.) and DurAND (A.), the choice of operation in chronic fronto-ethmoidal simusitis (abstract)

Jaws. upper and lower, casts of, from case of chronic middle-ear catarrh (P. Nelson)

- see also Maxilla.

JOAL: pharyngitis sicca and Bright's disease (abstract)

Jones (H. E.), on a sequestrum comprising the internal auditory meatus. the superior and posterior semicircular canals, and the greater part of the vestibule

- discussion on tubereulosis of ear, nose. and naso-pharynx - guides to surgical relations of facial nerve, etc., in the temporal lone

ation illustrating $(a)$ temporo-

sphenoidal abscess; (b) superficial cerebellar abscess: (c) basal meningitis; $(d)$ sinus thromhosis ; $(c)$ extensive destruction of hone in hereditary syphilis and scarlatina ; $\left(f^{+}\right)$cases of the complete postamal operation with and without grafting; $(y)$ specimens (pathological and anatomicil) 
JORDAN (C. H. R.) and KNAPP (Arnold) : a brief report of forty radical operations for chronic purulent otitis and complications, with remarks (abstract) .

JoURDRAN and Fontoynont : streptococeal glossitis and stomatitis in Madagascar (abstract)

Jugular bulb : thrombosis, two cases (N. H. Pierce)
Jugular vein (internal) : exposure and irrigation of bulb of internal jugular vein in operation for septic sinus thrombosis (Zoufal)

- ligation in two cases of thrombosis of jugular bulb

(N. H. Pierce)

$$
\text { operative exposure of hulb of (Muck) }
$$

JüRGENS (E.), three cases of congenital atresia of the external auditory meatus with microtia (abstract)

KAMM (M.), acute mastoiditis complicated by scleroderma (abstract)

KELLY (A. Brown), microscopical sections of nasal growths of the type of " bleeding polypus of the septum:" (1) and (2). bleeding polypi of the septum; (3) alar polypus; sarcomatoid tumour of the septum .

KeLson (W. H.). case of laryngeal growth in a woman

- case of nasal tumour in a man aged twenty-six - a case of bleeding polypus of the nose in a girl aged fifteen - a case of dislocation of bones of the nose, due to polypi. in a man aged sixty .

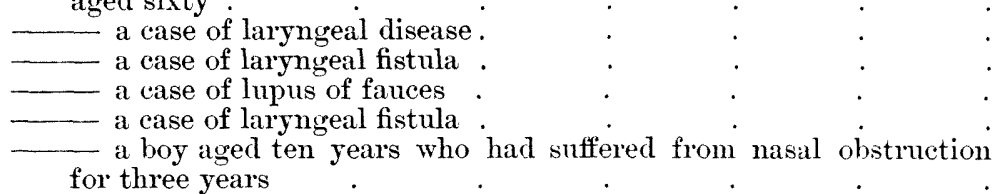
Killian's operation in cure of bilateral frontal sinus empyema (W. Petersen)

KING (Gordon), adenoma of palate (abstract)

KLUG: contagion in acute middle-ear disease (abstract)

KNAPP (Arnold), on a case of cerebellar abscess after infection through the labyrinth; death from meningitis; autopsy (abstract). - osteomyelitis of the skull, with empyema of the nasal accessory cavities ; sinus thrombosis ; pyæmia ; death ; autopsy (abstract) - and Jordan (C. H. R.), a brief report of forty radical operations for chronic purulent otitis and complications, with remarks (abstract)

KoERNER (O.), the usual methods of treatment and operation in the ear and throat clinic at Rostock (abstract) .

Körte (W.), case of implantation of the facial to the hypoglossal nerve (abstract)

KyLE (D. Braden), the import of the salivary and nasal secretions in hay fever

Labyrinth, infection through, causing cerebellar abscess; death from meningitis; abscess (A. Knapp)

- meningitis; abscess (A. Knapp) $\cdot$.

LACK (H. Lambert), case of complete adhesion of soft palate to posterior wall of pharynx

- a case of functional aphonia in a man, with unusual symptoms.

sections of ulcer of tonsil containing tubercles, which yielded to antisyphilitic remedies a case of functional aphoni larynx and palate in a boy sections of cedematous thickening of 
LACK (H. Lambert), a case of multiple sinus suppuration, showing the results of operation upon sphenoidal sinus with demonstration of a new instrument

LACOARRET : muco-papillomatous polypi of nasal septum

LAKE (Richard), case of removal of the epiglottis for tuberculous disease in a male aged thirty-five

- on a case of foreign body in the naso-pharynx (abstract)

discussion on tuberculosis of the ear, the nose, and the naso-

pharynx

- exhilition of section of new growth removed from the posterior extremity of the inferior turbinate body (right) of a man aged fifty - exhibition of section of right inferior turbinate

exhibition of section of recurrence of new growth involving left inferfor turbinate and septum

- microscopical section of a tuberculous pachydermia from the pro-

cessus rocalis

case of laryngeal tuberculosis

a case of ulceration of tonsil

PAGE

posterior aspect of cricoid cartilage ; $(2)$ papilloma from region of inferior turbinal

- the restoration of inferior turhinate body by paraffin in the treatment of atrophic rhinitis (abstract)

LAmb (W.). discussion on the upper respiratory tract as a source of systemic infection

Lantern demonstration showing the normal fluctuations of air-pressure in upper respiratory tract (Scanes Spicer)

DE LAPERSONNE : the oculo-orbitary complications of sinusitis (abstract)

Larynoitis, chronic, with interarytænoid pseudo-pachydermic swelling, probably due to purulent rhinitis (J. Dundas Grant)

W with papillated thickening of roeal cord and chronic

rhinitis (J. Dundas Grant)

Toul) (hypertrophica), following prolonged nasal trouble (Hunter

Laryngological Society of London : proceedings 89, 212. 245, 320, 364, 4:2, 430

Leport of Morbid Growths Committee 2. 255, $36 \pm$

Laryngology : adrenalin. use in oto-rhino-laryngology (V. Delsaux) . 223

position in medical students curriculum (P. Watson Williams) . 461

- retrospect of, 1902 (John Macintyre. M.D.)

section of Laryngolosy and Otology at annual meeting of British

Medical Association (1903)

$408,461,513,565,648$

- section of Laryngolory and Rhinology, Fourteenth International

Medical Congress, Madrid

Laryngoscopy: "Oto-rino-laringoseopia ed esofagoscopia " (L. V. Nicolai : review)

Larynx, abstracts of literature on

51. 104, 164, 2211. 276, 333, 501, 557, 610

- cancer, case cured by $\mathrm{X}$ rays (W. Scheppegrell) .70 results of treatment by means of X rays (D. B. Delavan) 51,276 surgical treatment (E. J. Moure) cyst of ventricle of, opened when operating on a case of malignant

disease (H. Lambert Lack)

- disease of, case of (W. H. Kelson) :

employment of high-frequency currents in oto-laryngology

(Mouret and Denoyes)

two cases remaining well two years after operation 

growth of (V. Wyatt Wincrave) . in a woman (W. H. Kelson). prumma of sequel of case (C. Nourse) involved in case of nevus (P. H. Abercromlie) (lesions) : case of pharyngeal and laryngeal lesions (J. Donelan). :37:3 lupus of (V. Wyatt Wingrave) 312. 414 malignant disease ; operative treatment . . 449 (Professor T. Gluck) . . . . 482

(Sir F. Semon)

malignant growth of larynx (Mayo Collier)

narrowing (abnomal) of larynx, probably congenital; specimen

(A. Logan Tumer) obstruction of (W. R. H. Stewart) œdema, chronic case; ? amyloid (J. Dundas Grint)

artificial production of cedema (A. Logan Turner) . edematous thickening of (H. Lambert Lack) · $\quad \begin{gathered}330 \\ 2+i\end{gathered}$ pachydermia of (V. Wyatt Wingrave) .

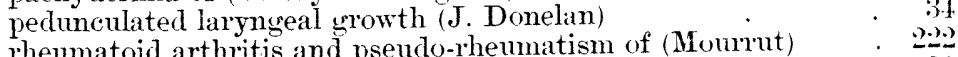
rheumatoid arthritis and pseudo-rheumatism of (Mourrut) sarcoma of, primary (C. Hödemoser) stenosis due to amyloid degeneration in (W. Courvoisier) tubercular: case treated by tracheotomy (J. Price-Brown) 4 , Sh, swelling of right side : case for diagnosis (H. J. Davis) syphilis (tertiary) affecting (P. de Santi) . tubereulosis of (C. Nourse) Nourse). 199

LAWRENCE (L.A.), a case of a woman aged thirty-seven, with ulceration of the soft palate

Lead-poisoning, paralysis of left vocal cord due to (C. J. Symonds)

LEAVEN (H. N.), otitis media (abstract) . .

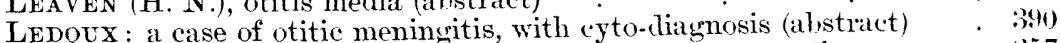

LEE (C. G.), two cases of epithelioma of auricle (after operation) . 357 case of acute otitis media and antrum disease (after operaltion)

LeNorR (A.), on the morphological value of the supra-meatal spine and tache spongieuse in antrectomy (alsstract).

LER MOYEZ (Marcel), after-treatment of operations on the ear . - and MaHu (Georges). treatment of certain affections of upper. respiratory tract. specially of vaso-motor rhinitis, by hot air

LEROY (Raoul) and Vessin (Lucien). the hygienic treatment of exophthalmic goitre (ahstract)

LEvYY: cannula for washing out attic and sinus (ahstract)

Lieves (Anton), on the treatment of syphilitic disease of the mucous membrane of the mouth and throat (translated by Arthur $J$. Hutchison)

Life insurance and diseases of ear (Wendell C. Phillips)

Light treatment of lupus vulgaris of respiratory mucous memlines at Finsen Light Institute, Copenharen (Hans B. Christiansen) _. 507

Lipoma of tonsil (C. F. Theisen). . 44\%

Liverpool. meeting of Otological Society of Great Britain at : . $\quad .81$

Localisation (cortical) of auditory area (A. Camphell) . $\quad 399.83 .4$

LOEB (H. W.), carcinoma of the epipharynx (abstract) . . . . - .

LODGE (Samuel), case of thrombosis of the cavernons sinuses . . : 841 - discussion on the technique of operations on the temporal hone in suppurative middle-ear disease . . . . . 539 
LoRTHIOIR : a clinical lecture upon the treatment of croup and diphtheria (abstract)

Love (James Kerr), exhihition of stereograms of sections of the temporal bone.

- the method of dealing with and developing the residual hearing power and speech of the deaf .

LUBET-BARBON : pengawar-djambi as a hemostatic agent in nasal operations (abstract)

LUBLINSKI (M.), acute purulent perichondritis of nasal septum (abstract)

Lung. expectoration of tooth thirteen months after inhalation into (W. E. Carnecrie Dicksom)

Lumgs, tuberculosis, laryngeal and pulmonary (V. Wyatt Wingrave) Limus of fauces (W. H. Kelson)

- of larynx (V. Wyatt Wingrave)

(?) of nose and face (D. Vimace)

\section{of nose, palate, and larynx (V. Wyatt Wingrave)}

of upper respiratory tract ; treatment ly ratium (V. Delsaux)

(old-standing), necessitating tracheotomy, in an elderly woman

(C. Nomrse)

- rapid destruction of nasai septum. prohally lupus (V. Wyatt Wingrave)

PAGE:

221

(s. of respiritory mucous membanes: occurrence and treatment in Finsen Light Institute of Copenhagen (Hans B. Christiamsen)

Lymphatic glands (cervical) enlargenent, acute and considerable, in a case of ulceration of left tonsil; (†) malignancy (Sir F. Semon) on both sirles of neck, enlarvement of in case of ulceration of left tonsil (Sir F. Seuron)

McBride (P.), a case of anosmia .

introductory remarks in discussion on the technique of operations on the temporal bone in suppurative middle-ear disease (reply).

McDougall (J. E.), a new method of treating adherent soft palate

Mackenzie (George Hunter). olvituary notice

McKeown (David), on chronic sphenoidal suppuration (abstract) deafness

McKernon (James F.). treatment of the complications of otitis media suppurativa

Macnaughton-Jones $(\dot{H}$.) and others, "Practitioner's handlook of diseases of the ear and naso-pharynx" (review). .

Madagascar : streptococcal glossitis and stomatitis in Madigascar (Fontoynont and $\vec{J}$ ourdran)

MaHU (Georges), on a sign which is pathognomonic of true chronic max-

illary sinusitis respiratory tract. specially of vaso-motor rhinitis, hy hot air

Malay Archipelago, otomycosis of (D. J. Gatloway)

Malformation of cesophagrus; specimen (F. J. Steward)

Malignant disease of larynx: operative treatment (Prof. T. Gluck)
(Sir F. Semon) in neigh hourhood of vight Eustachian tube (E. B. Waggett) of naso-pharynx (Barclay J. Baron). of right rocal cord: cyst of ventricle of larynx opened when operating on (H. Lamliert Lack) 
Malionant growth of middle ear (W Permewan)

Margo Collier)

Malignant ulcer of oro-pharynx (V. Wyatt Wingrave)

MANasse (Paul), a study of the pathology of the internal ear and the auditory nerve (ahstract)

Marage: the scientific treatment of deafness
Martinead (A. J.), on a case of saddle nose treated by subcutaneous injection of paraffin (abstract)

Mastoid antrum, purulent : inflammation, primary acute of mastoid cells involving neither middle ear nor mastoid antrum (J. Dunn) . 293 disease: unusual cases (H. Bert Ellis) . . . 502

inferior occipital plate of the mastoid, with especial reference

to Bezold's mastoiditis (J. Dumn) operation, radical (C. Jackson)

significance of rariations in course of facial nerve in $(H$. Schwartze)

Alex. Randall) variations in course of facial nerve bearing upon (M. - operations (radical) : after-treatment without packing (A. Zur Muehlen)

- suppuration behind mastoid and in posterior fussa associated with ear disease, but without perforation of membrane (W. Permewan) .

Mastoiditis, acute, accompanied by scleroderma (M. Kamm) treatment, conservative (S. F. Snow) .

(Bezold's) and inferior occipital plate of mastuid (J. Dimn)

due to gonococeus (C. Trow)

exophthalmos following (H. L. Secord)

following primary tulerculosis of the ear; report of four cases

(M. A. Goldstein)

Masto-sfuamosal suture (Aderman)

Maxilla (superior), tumour of (C. F. Forsham)

Maxilla see also Jaus.

Maxillary node in an infant ( $\mathrm{V}$. Wyatt Wingrave) . . .

Meatus (external anditory), atresia (congenital) with microtia; three cases (E. Jürgens) ceruminous glands from the cartilaginous portion of $(V$. Wyatt Wingrare)

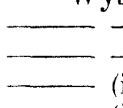
_ epithelioma of (J. Dundas Giant) specimen (V. Wyatt Wingrave)

(inferior), trepanation of maxillary sinus by way of (Vaquier) meatus, superior and posterior semicircular canals, and greater part of restibule (Hugh E. Jones) .

(left amal), remoral of large hyperostosis of (H. Tilley)

tumour of, associated with an abdominal tumour (A. H. Cheatle)

Medical student: position of laryngology and otology in his curriculum (P. Watson Williams)

Meierhof (E. L.), does early treatment of acute inflammation of the midule ear prevent the nore serious complications : (abstract)

MELzI (Urbano), naso-pharyngeal fibroma cured by means of galvanocautery puncture (translated by James Donelan)

Membrana tympani : perforation absent in case of suppuration hehind mastuid and in posterior fossa, associated with ear disease (W. Permewan)

- value of exploratory puncture of (D. Roy)

cause of death in catse of cerebellar abscess after infection through lahyrinth; autopsy (A. Knapp) . . . 110 - (otitic) case. with (ytu-diaynosis (Ledoux) $\quad: \quad 5 \cdot \quad: 390$

(tuberculous), temporal bones removed from patients who died of (A. H. Cheatle) . 


\section{Index.}

Menzer (K MI), treatment of insuction of the alde nasi (abstract)

Micro-millimetres, acoumetry in (H. J. L. Struyschen)

Microtia in three cases of congenital atresia of external auditory meatus (E. Jürgens)

Middle ear : see $E a r$ (middle).

Miligigan (W.), retrospect of rhinology - the diagnosis and treatment of tuberculous disease of the middle ear and its accessory cavities.

- reply to discussion on tuberculosis of ear, nose, and naso-pharynx specimens and micro-photographs illustrating tuberculous disease of the ear and naso-pharynx two cases of chronic suppurative middle-ear disease

Model (working), readily improvised. to demonstrate the air-chamnels and currents in the nasal cavities in normal and impeded nasal respiration (Scanes Spicer)

Montfort: acute pemphigus of the upper mucous membranes (abstract)

Morlid Growths Committee of Laryngological Society of London. reports

"Morcellement" used to remove through mouth primary growth in case of advanced and inoperable epithelioma of epiglottis, with secondary infection of cervical orands (Herbert Tilley)

Morse (J L ) retro-pharyncal abscess in children (abstract) .

MOSETIG-MOORHOF : iodoform bone-stopping (abstract) . $\quad 341$

Motre (E. J.), a case of empyema of the right maxillary antrum and hoth frontal sinuses, with necrosis of the orbital wall (abstract) - is atrophic coryza an autonomous affection: diagnosis and treat. ment

stuly of labyrinthine suppuration and necrosis
the surgical treatment of cancer of the larynx (translated by Chichele Nomrse)

C and BRINDEL, ultimate results of paraffin injections into nasal mucosa in seventy cases of typical ozænatous atrophic rhinitis

Momre's operation, cases of deflected septum treated hy (L. H. Pegler) .

- septotome for use in Moures and other operations in deflection (L. H. Peuler).

Motret and Devores: on the employment of high-frequency currents in oto-laryngology (ahstract)

Mocrevt: Theumatoid arthritis and pseudo-rheumatism of larynx (abstract) .

Mouth : abstracts of literature on. (diseases): "Atlas and epitome of diseases of the month, pharynx. and nose" (L. Grïnwald : review)

- (inflammation of): see Stomatitis.

nasal obstruction and deformities of the upper jaw, teeth. and

palate (Mayo Collier)
- syphilis of mucons membrane of ; treatment (A. Lieven) vilcers, strumous, of (W. R. H. Stewart)

Mucin, heneficial effect of. in atrophic rhinitis (Mr. Stuart-Low)

MLCk: the occurience of rhodan in the nasal secretion, and its alsence in ozæna (abstract)

- entotic murmur due to aneurysm of occipital artery (alistract)

Mucoid cyst : see Cyst (mucoid).

Mucous membrane in interarytanoid region, large swelling of (so-called interarytænoid "pachydermia") (H. Tilley) of month and throat, syphilis of, treatment (A. Lieven) - (of nose), paraffin injections into, in cases of ozanatous atrophic rhinitis (Mome and Brindel). of septum nasi. localised psorospermusis of ; microsconic: section (Captain O'Kinealy) 375; microscopical report (Major J. C. Vatughan). 
Mucous mentranes (respiratory) : lupus vulgaris of respiratory mucous membranes; occurrence and treatment in Finsen Light Institute, Copenhagen (Hans B. Christiansen)

(upper), pemphigus of (acute) (Montfort)

Mucous patches of tonsils (H. Lambert Lack)

Murmur (entotic) due to aneurysm of occipital artery (Muck) .

Muscles of palate and pharynx, clonic spasm of, causing entotic tinnitus (L. H. Pegler)

Myxcedema, deafness due to (J. Diindas Grant)

Myxo-fibroma, probable, of nose (S. W. Allen)

Myxo-sarcoma in nasal cavity (Mayo Collier)

Nævus: case involving uvula, palate, fauces, tongue, and larynx (P. H. Abercrombie)

Narrowing (abnormal) of larynx and trachea, probably congenital; specimen (A. Logan Tumer) .

Nasal cavity : see Nose.

Naso-pharynx : abstracts of literature on 101, 160, 218, 274. 331, 5.56. 609, 67.2 carcinoma, columnar-celled; specimen (A. Bronner)

___ (diseases of) : "Practitioner"s handbook of diseases of the ear and naso-pharynx" (H. Macnaughton Jones and others : review)

\section{fibroma of (J. Dundas Grant)}

Melzi) cured by means of gralvano-cautery puncture (L. specimen (V. Wyatt Wingrave)

$-$ (vascular), of extensive orisin, finally removed throush the soft and hard palate, with extensive removal of anterior wall of left supra-maxillary bone (Herhert Tilley)

- fibro-myxoma (large), with prolongations extending to anterior nares (J. Donelan)

\section{foreign body in ( $\dot{R}$. Lake)}

malignant disease of (Barclay J. Baron)
part played ly naso-pharynx as source of general septic infection

(H. Tilley) (syphilis, tertiary, of) : tertiary lesions in naso-pharynx (Dieu) tuberculosis of, discussion on (Urban Pritchard, C. A. Ballance, A. E. Cumber-

l.atch, A. L. Whitehead, Hugh Jomes, A. Cheatle)

Tectuherculous disease of (W. Milligan)

Neck : ulceration of left tonsil with acute and considerable enlarcement of numerous cervical lymphatic glands on both sides of the neck; malignancy (Sir F. Semon)

Necrosis of labyrinth (E. J. Moure) and both frontal sinuses (Moure)

Nelson (Philip), casts of upper and lower jaw from a case of chronic middle-ear catarrh

Nerve (auditory), pathologry of (P. Manasse) surgical relations of, in temporal hone $(\mathrm{H}$. E. Jones)
variations in course, and their sionificance in mastoil operation (H. Schwartze) ariations in course bearing upon mastoid operation (M. hypoglossal) : implantation of facial nerve to hypoglossal (Körte) (laryngeal) : paresis of both recurrent laryngeals and left sympathetic (J. Dundas Grant) - (left recurent), large aneurysm of arch of arta shown hy radioscopic examination in case of ( $V$. Cheval) pathetic (J. Dundas Grant) 
Nerve (trigeminal): taste fibres and their independence of the nervus trigeminus ( $\mathrm{H}$. Cushing)

Nerve-deafness due to tobaceo (V. Wyatt Wingrave)
Nerves (cerebral) : early and unusual implication in cases of talies (Sir F. Semon)

Neuralgia (cranial) from intra-nasal and sinus pressure (S. F. Snow)

Neurasthenia of intra-nasal origin (C. Compaired)

Newcoms (James E.): see Grinucald (L.). "Atlas and epitome of diseases of the mouth, pharynx, and nose."

Nicolar (L. V.), "Oto-rino-laringoscopia, ed esofagoscopia : anatomia topografica e metodi di esome del naso-faringe, larynge, orecchio, ed esophago" (review) .

NicoLLE and HEBERT : sore throat due to the pneumohacillus of Friedlinder

Node (maxillary) in an infant (V. Wyatt Wingrave) .

Noises (oljective) in pharynx catused hy clonic spasm of soft palate ( $L$. H. Pegler)

Nose, abstracts of literature on

51. 102. 162. 218, 275, 333. 384, 439, 300. 5.56. 609,672 (accessory sinuses), anatomical method of demonstrating the accessury cavities of ( $G$. Bruehl)

- duplicity of (G. Brnehl) empyema of. in case of osteomyelitis of skull (A. Knapp). - suppuration. chronic (A. P. Crocket) .

Tilley) tuberculous disease of nasal carities, case illustrating $(\mathrm{H}$.

(ala), polypus of (A. Brown Kelly) :

(alic) : treatment of insuction of ala nasi (K. ir. Menzel) (bleeding from) : see Epistuxis.

(bones of) : dislocation of bones of nose caused by polypi (W. H. Kelson)

deformity, case of (W. R. $\dot{H}$. Stewart)

(diseases): "Atlas and epitome of diseases of the mouth, pharynx,

and nose" (L. Grïnwald : review)

"Diseases of nose, pharynx, and ear ". (H. Gradle : review)

- displacement, extreme (Mayo Collier)

(H. Gradle: review)

foreign body remored from (W. L. Ballenger)

hyperamia, persistent. superficial, cured by removal of adenoidis

(V. Wyatt Wingrave)

- injection of paralfin into nose followed hy immediate blindness

(L. Mi. Hurd)

laryngitis hypertrophica following prolonged nasal trouble

(Hunter Tod) lupus of (V. Wyatt Wingrave)

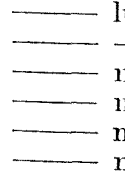
(:) (D. Vinmace) myxofibroma, probable case of (S. W. Allen) : myxosarcoma in nasal cavity (Mayo Collier). nasal treatment of asthma (A. Francis)

- neurasthenia of intra-nasal origin (C. Compaired)

- obstruction of, and deformities of the upper jaw. teeth, and palate (Mayo Collier) case of three years duration (W. H. Kelson)
(operations on) : pengawar-djambi as hamostatic agent in nasal operations (Lubet-Barbon) part played by nose as source of general septic infection (H. Tilley) (polypus) : case of hleeding polypus (W. H. Kelson)

local use of formalin in treatment of masal polypi $(A$ Bromner) . polypi causing dislocation of nasal hones (W. H. Kelson)

and caly improvised working model to demonstrate the air-chitunel and nasal cavities in normal and impered respiration (Scanes Spicer) 
Nose, sarcoma of (J. Price-Brown) . . . . $\quad 398$

Nose, sarcoma of (Muck)

Kyle)
(septum) : abscess, bilateral, with well-marked symptoms of septi-

camia (W. L. Culbert) . . . abscess of septum nasi following left antral empyema

(Hunter Tod) - absence, in unusual case of frontal sinusitis (C. G.

Coakley) . . . . 596

$-\begin{array}{lll}\text { deflected, treated by Moures operation (L. H. Pegler) } & \cdot & 596 \\ - & 205\end{array}$

Horne)
-
- (R. Lake)
mumma of (L. H. Pegler) . . . . . . . $\quad 216$

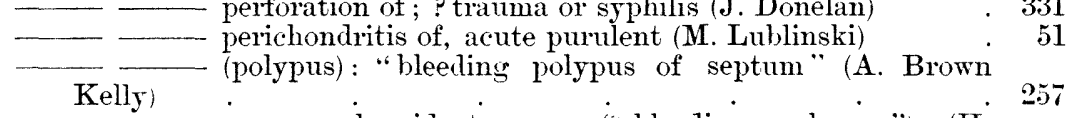

Kelly) $\frac{\cdot}{\text { Tod }}-$ polypoid tumour ("bleeding polypus ") (H. nasi ; microscopical section (Captain O'Kinealy) • (Major • J. C.

Vaughan) .

grave) - rapid destruction, probably lupus (V. Wyatt Win- sarcomatoid tumour of (A. Brown Kelly) tubercular ulceration of (primary) (E. B. Waggett) . $4: 26$ - tuberculous tumour on posterior part of (Bellevue) $\quad 218$ short operations, choice of anwsthetic in (J. H. Chaldecott) 111 (sunken), paraffin injection for (S. Paget) . $\quad 61,103,27.5$ see also Saddle-nose.

(suppuration in): cases of pyogenic lrain disease associated with

or caused by acute or chronic nasal suppuration (T. Hubbard) . 628 tuberculosis of, discussion on $\quad . \quad 188$

(Urban Pritchard. C. A. Ballance, A. E. Cumber-

batch. A. L. Whitehead. Hugh Jones, A. Cheatle) . 154-160

— tumour of (W. H. Kelson). $\quad . \quad$. $\quad . \quad 254$

-1 (C. Nourse, V. Wyatt Wingrave) . . $\quad . \quad 415$

—_ restibule, papilloma of (W. Johson Home) . . . . $\quad$. 643

- tumour of (E. Cresswell Baber) . . . 322

- see also Rhinotomy.

- see also V'rtigo (nasal).

Nostril, epithelioma of (V. Wyatt Wingrave) . . . . . . . . .

Nostrils (anterior): prolongations of large naso-pharyngeal fibromyxoma extending to anterior nares (J. Donelan)

myxoma extending to anterior nares (J. Donelan)
(posterior) occlusion of right posterior nares (H. D. Hamilton)
Nourse (W. J. Chichele), a case of laryngeal tuberculosis in a woman

agred thirty-five note on new form of infundilular probe and cannula for frontai sinus. and a probe and cannula for sphenoidal sinus . 298,418

- a case of old-standing lupus necessitating tracheotomy in an elderly woman
a case ot tertiary syphilis affecting the larynx in a man aged fifty-one

- a case of new growth on the nose externally, presenting an

unusual structure . . . . . . . . . 415

$\longrightarrow$ the sequel of a case of gumma of the larynx, shown a year ago $\quad \cdot \quad 419$

concerning radium and exhibition of specimens 
Nourse (W. J. Chichele), the surgical treatment of cancer of the larynx

(by E. J. Moure: translated by Chichele Nourse)

- and Grant (J. Dundas), retrospect of otology, 1902 . . 12

Obituary notice : Mackenzie, George Hunter, M.D. . · · · 1 Walsham, William Johnson . . . 617

Obstruction, absent in cancer of cesophagus (J. G. Emanuel) . . 105

(nasal) and deformities of the upper jaw, teeth, and palate (Mayo Collier) $\begin{array}{lll}\text { (subjective nasal), in a case of comparative hemiantesthesia (J. } & & 101 \\ \text { Dundas Grant) } & & 99\end{array}$

Dundas Grant)
clusion of right posterior nares (H. D. Hamilton)

Oculo-orbitary complications of sinusitis (F. de Lapersonne) $\quad . \quad 2 \quad .200$

Edema of larynx, chronic case (? amyloid) (J. Dundas Grant) . . $266^{3}$ - series of anatomical preparations demonstrating the artificial production of (A. Logan Turner)

Edematous thickening of larynx and palate (H. Lambert Lat $\cdot \vec{k}$ )

Esophagoscopy : "Oto-rino-laryingoseopia ed esofagoseopia " (L. V. Nicolai : review)

Esophagus : ahstracts of literature on $\quad \cdot \quad$. $\quad 105,222.385,502$

- c . . . . . . . . 30

- without obstruction (J. G. Emanuel) . . . 10.5 - carcinoma, etiology (Wolf) . . . 385 - dilatation, diffuse ; etiology from clinical point of view (Starck) . 385

___ (foreign bodies in) : removal of foreign bodies from cesophagus by

an improved method of using the Röntmen rays (G. Hamilton) . 20.2.2

- foreign body in osophagus (J. Macintyre. M.D.) . . . $\$ 1$

- malformation of. specimen (F. J. Steward) . . . 90

- malignant stricture of upper end of : specimen (A. Logain Tumer) gts

- perforation of. by tuherculous glands (C. Riviere) . 2.2.2

__ "pressure pouch" removed hy operation in eight cases $(H . T$. Butlin)

O'KINEALY (Captain), a microscopic section of localised psorospermosis of the mucous membrane of the septum nasi

OLMSTEAD (Ingersoll), the operative treatment of (noitre (abstract)

Oro-pharynx, malignant ulcer of; specimen (V. Wyatt Wingrave) . 644

Ossiculectomy (E. B. Dench)

Osteomyelitis of skull, with empyema of nasal accessory cavities: sinus thrombosis ; pyæmia ; death (A. Knapp)

Ostmann (Professor), an objective uniform measure of hearing as supplied by the amplitude of vibration of Edelmann's $\mathrm{C}$ and $\mathrm{G}$ tuning-forks (author's abstract : translated by Dr. Westerman)

Otic origin. cerebellar abscess of (V. Gillot)

Otitic origin of two cases of cerebellar abscess (Gaudier)

Otitis (chronic purulent) and complications, lrief report of forty radical operations for (A. Knapp and C. H. R. Jordan)

Otitis media (H. N. Learen) therapentics of (G. W. Hopkins)

" purulent: two severe acute cases caused by "Schneeberger" snuff powder (Schroeder)

(chronic). etiology. symptomatology, and pathology of (C. W. Richardson) technique of radical operation for (E. B. Dench) 
Otitis: recorery from otitic pyæmia (C. Breyre) (suppurative), amelioration of hearing troubles caused by (B. Gomperz)

Otological Congress, Seventh International, notice respecting.

Otological Society of the United Kingdon, meetings

- meeting at Liverpool notice respecting extra metropolitan meeting :

Otology: "Atlas and epitome of otology" (G. Brïhl and A. Politzer : review)

review) position in medical students' curriculum (P. Watson Williams) retrospect of, 1902 (J. Dundas Grant and Chichele Nourse) corrigendum (section of) at International Medical Congress

Otomycosis of the Malay Archipelago (D. J. Galloway)

Otoscopy : "Oto-rino-laringoscopia, ed esofagoscopia"

(L. V. Nicolai : review)

Ozæna, absence of rhodan in (Muck)

- etiology of (W. Freudenthal) of tracheal causing dyspnœa (Dupond)

Ozone in chronic middle-ear deafness (G. Stoker)

"Pachydermia," interarytanoid, so-called (H. Tilley) . tuberculous, from processus rocalis; microscopical section $(R$. Lake)

Packing: after-treatment of radical (mastoid) operations without packing (A. Zur Muehlen)

Paget (Stephen), on paraffin injections in cases of sunken nose.

- a lecture on the use of paraffin for sunken noses (abstract)

Palate, adenoma of (G. King)

- clonic contraction of (F. J. Steward)

- clonic spasm of muscles of palate and pharynx causing entotic

tinnitus (L. H. Pegler)

- (hard), abscess of, following left antral empyema (Hunter Tod)

lupus of (V. Wyatt Wingrave)

cdematous thickening of (H. Lambert Lack) .

paralysis of cords, with slight paresis of the tongue (J. Dundas Grant) .

\section{(soft), adherent, new method of treating (J.E. McDongall)}

adhesion. almost complete, to posterior pharyngeal wall relieved by operative procedure $(H$. Tilley)

H. Perler) clonic spasm in, causing objective noises in pharynx (L.

Hegler) (disease of), combined syphilitic and tuberculous (V.

Wyatt Wingrave)

infant (H. FitzGerald Powell).

Semon) infiltration of (? cause) (F. J. Steward) 
Papilloma from region of inferior turhinal; microscopic specimen ( $R$.

Liake)

from posterior aspect of cricoid cirtilage (large); microscopic

specimen (R. Lake)

$4: 4,425$

of right rentricular band (large) removed by thyrotomy (E. B.

Waggett)

of vestibule of nose (W. Jobson Horne)

Paraffin: injection into nose followed by immediate bindness (L. M. Hurd) \begin{tabular}{c} 
injection of, for sunken noses (S. Paget) \\
in case of so-called saddle-nose (F. Alter) \\
\hline infections in the treatment of atrophic rhinitis ; restoration of \\
inferior tuate body (R. Lake)
\end{tabular}

tion for chol two cases of large retro-auricular opening (after opera-

into nasal mucosa in cases of ozznatous atrophic rhinitis (Moure and Brindel) .

Martineau) (subcutaneous) in treatment of saddle-nose

(A. J.

aralysis (bilateral ahductor) in girl aged fourteen, following tonsillotomy ( $V$. Wyatt Wingrave) (facial) : operative treatment of chronic facial palsy of peripheral origin (C. A. Ballance, H. A. Ballance, and Purves Stewart)

sulsiding rapidly after removal of cholesteatoma by operation (J. Dundas Grant)

of abductors of the vocal cords and of the palatal muscles, with

slight paresis of the tongue (J. Dundas Grant) .

of left recurrent nerve : large aneurysm of arch of aorta shown

hy radioscopic examination (V. Cheval).

Paresis of hoth recurrent laryngeals and left sympathetic (J. Dundas Grant)

- of tongre (slight) in case of paralysis of the abductors of the vocal cords and palatal muscles (J. Dundas Grant)

Parker (C.A.), case of double abductor paralysis with swelling of the

arytienoids in a man aged thirty-eight .
case of persistent epistaxis in a man aged forty-two

Paterson (Andrew), the morphology and derelopment of the temporal hone the development and morphology of the ear.
PATERson (D. R.). discussion on the upper respiratory tract as a source
of systemic infection

Pathological specimens, demonstration of (H. E. Jones)

PEGLER (L. H.), cases of deflected septum treated by Moure's operation
septotome for use in Moure's and other operations for reflection

- an aural case for diagnosis in girl aged eighteen

- case of entotic tinnitus in a lady aged thirty . $\quad . \quad 314$

- unusual experience after partial turbinotomy . a case of clonic spasm of the muscles of the palate and pharynx 316 causing entotic tinnitus in a lady aged thirty p. in a case of clonic spasm of the soft palate causing objective noises in the pharynx in a woman aged twenty . . 372

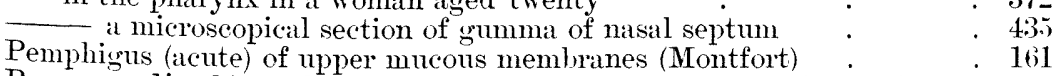

Pengawar-djambi as hæmostatic agent in nasal operations (Lubet-

Barbon)
Perforation (hereditary specific) of anterior pillar of fances $(\dot{J}$. Dundas

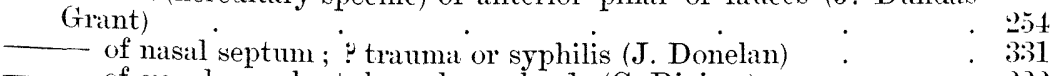

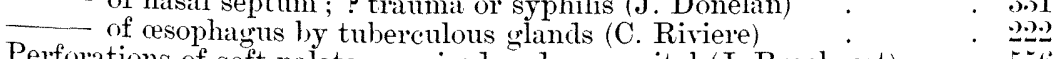

Perforations of soft palate, acquired and congenital (J. Brockiert) . .5.5 
Perforator: see Screw perforator.

Perichondritis of nasal septum, acute, purulent (M. Lublinski)

Permewan (W.), a case of suppuration behind the mastoid and in the posterior fossa, associated with ear disease, hut without perforation of the membrane

sections of malignant growth of midile ear .

Petersen (W.), bilateral frontal simus empyema cured by Killian's operation (abstract) .

Pharyngitis (chronic hypertrophic) : treatment ly scarification (Escat) - sicea and Bright's disease (Joal)

Pharynx, abstracts of literature on

- adhesion (complete) of soft palate to posterior wall of pharynx (Lambert Lack)

- clonic spasm of muscles of palate and pharynx causing entotic tinnitus (L. H. Pegler) (disease of), combined syphilitic and tuberculous (V. Wyatt

Wingrave)

(diseases) : "Atlas and epitome of diseases of the mouth. pharynx. and nose" (L. Grïnwald : review) epithelioma of pharynx and tonsil; specimen (V. Wyatt Wingrave)

Grant) probable in a case of increasing aysphagia $(\dot{J}$. Dundas

hypertrophy of the lymphoid ring of

infiltration of (H. FitzGerald Powell)

H. Butto)

(lesions) : case of pharyngeal and laryngeal lesions (J. Donelan) . 373 ulceration (recurring) in pharynx, thought to be herpetic (E. Fumiss Potter)

(wall of, posterior), almost complete adhesion of soft palate to. relieved by operative procedure $(\mathrm{H}$. Tilley)
ILLIPS (W. P.), treatment of acute suppurition of middle ear (abstract).

life insurance and diseases of the ear
PIERCE (Norval H.), the etiology and pathology of otitis media suppurativat two cases of thrombosis of the jugular bulb; ligation of the internal jugular

PrfFr: the operative exposure of the bulb of internal jugular rein (abstact)

Pillar of fauces (anterior), ulcerating growth of left tonsil, side of tongne, and anterior faucial pillar (H. FitzGerald Powell)

- - hereditary specific perforation of (J. Dundas Grant)

Pinna: epithelioma; two specimens and microscopic sections (E. M. Stockdale) .

Politzer (Adam). "A text-book of the diseases of the ear for" students and practitioners" (translated : review).

" "Atlas and epitome of otology," by Gustav Bribl. with the collaboration of Professor A. Politzer. Authorised translation from the German. Edited by S. MacCuen Snith (review)

Polypi (muco-papillomatous) of nasal septum (Lacoarret)

(nasal): suppurative ethmoiditis and frontal sinusitis after radical operation for (A. Bronner)

Polypus of ala (A. Brown Kelly) . of nose: case of bleeding polypus (W. H. Kelson)

Kelson) dislocation of nasal bones caused by polypi

Post-aural operation: demonstration of cases of complete post-aural operation, with and without grafting (H. E. Jones) 
Post-nisal space, growth in, appearing below soft palate in infant $(H$.

FitzGrerald Powell)

- infiltration of (H. FitzGerald Powell)

swelling in (E. Furniss Potter)

Post-pharyngeal swelling (E. B. Waggett) .

PotTer (E. Funiss). case of recurring ulceration in pharynx and larynx, thought to be herpetic. in a woman aged fifty-six

case of disease of both frontal simuses in a man aged twenty-nine

- a case of singer's nodule (left rocal cord)

a case of swelling in post-nasal space

Powell (H. FitzGerald), case of cyst of the epiglotis in a male aged forty

case of growth in the post-nasal space appearing helow the soft

palate in an infant aged eighteen months as a aged forty-five

a case of ulcerating growth of the left tonsil, side of tongue, and anterior faucial pillar in a man aged fifty-two

Porston (Frederick J.), discussion on the upper respiratory tract as a source of systemic infection (pathology)

"Pressure-pouch" of cesophagus removed by operation in eight cases (H. T. Butlin)

Price-Brown (J.), notes on cases of sarcoma of the nose . . 398

- a case of tubercular laryngeal stenosis treated by tracheotomy . 498

Pritchard (Urban), discussion on tuberculosis of ear, nose, and nasopharynx

Prolie for sphenoidal sinus (W. J. C. Nourse) (infundibular) for sphenoidal sinus (C. Nourse) new form of (C. Nourse)

Processus rocalis, tuberculous pachydermia from ; microscopical section (R. Lake).

Pseudo-rheumatism of larynx (Mourut)

Psorospermosis (localised) of mucous membiane of septum nasi ; microscopic section (Captain O'Kinealy)

Puncture, exploratory, of membrana tympani, value of (D. Roy)
Præmia, fatal, with sinus thrombosis, in case of osteomyelitis (A. Knapp)

Pyogenic brain diseases, associated with or caused by acute or chronic nasal suppuration (T. Hubbard)

Quinine deafness and its prevention (A. Cheatle)

Radium. communication concerning, with exhibition of specimens (C. Nourse)

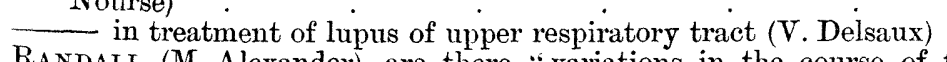

RANDALL (M. Alexander), are there "variations in the course of the facial nerve having bearing upon the mastoid operation?" (abstract)

Rash, wandering, on tongue (Mayo Collier) .

$\mathrm{R}_{\mathrm{A}} \mathrm{W}$ (Nathan), on human and bovine tuberculosis (abstract) .

RAI (J. M.), the inefficiency of the Wilde's incision (in operating for otitis media suppurativa)

Renault (A.), some cases of cancer cured hy Adamkiewicz's cancroine (abstract) .

Resection of trachea (Tétrop)

Respiration : lantern demonstration showing normal fluctuations of air-

pressure in upper respiratory tract (Scanes Spicer) to demonstrate the air-channels and currents in the nasal cavities (Scanes Spicer) 
Respiratory tract (aiseases), treatment of certain affections, specially vaso-motor rhinitis. hy hot air (M. Lermoyez and G. Mahu) (upper) as source of systemic infection : discussion at British

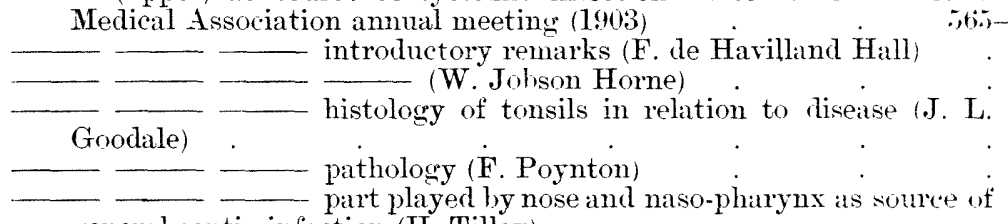
general septic infection ( $H$. Tilley)

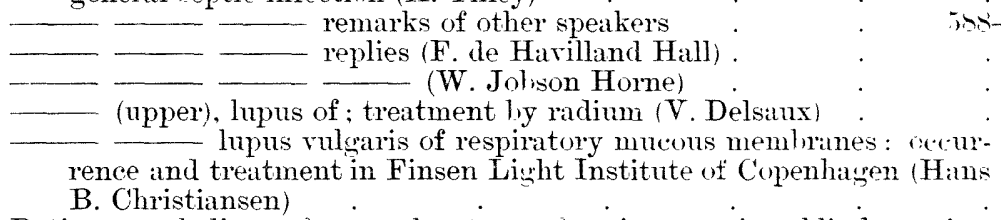

Retina: embolism of central artery of retina causing hlindness immediately after paraffin injection into nose (L. M. Hurd).

Retro-pharyngeal alscess : see $A b s c e s s$ (retro-pharyngeal).

Reverdin and Vallette : two cases of intra-cranial abscess . . . .

Reviews

Rheumatism : see Pseudo-rhermatism.

Rhinitis (atrophic), cases illustrating beneficial effect of mucin in $\left(\mathrm{M}_{\mathrm{r}}\right.$. Stuart-Low) - (atrophic), restoration of inferior turhinate body by paraffin injections in the treatment of ( $R$. Lake) . (chronic) with chronic laryngitis and papillated thickening of rocal cord (J. Dundas Grant) .

Grant) . . . . - (ozenatous, atrophic) paraffin injections into nasal mucosa in cases of (Moure and Brindel). arytanoid pseudo-pachydermic swelling (J. Dundas Grant) (vaso-motor) ; treatment hy hot air (M. Lermoyez and G. Mahu)

Rhinology, retrospect of. 1902 (W. Milligan)

Section of Larynology and Rhinology, Fourteenth International Medical Congress, Madrid exhibition of instruments at use of adrenalin in (V. Delsaux)

Rhinoscopy : "Oto-rhino-laringoscopia ed esofagoscopia " (L. V. Nicolai : review)

Rhinotomy (sublabial) (Galand)

Rhodan : occurrence in nasal secretion and its absence in ozena (Muck)

Richardson (Charles W.), the etiology. symptomatology, and pathology of otitis media suppurativa chronica

Riviere (Clive). perforation of the oesophagus by tuberculous glands (abstract) ,

Röntgen rays : aneurysm (large) of arch of aorta shown by radioscopic examination in case of paralysis of left recurrent nerve (V. Cheval) . cancer of larynx; case cured by $\mathrm{X}$ rays (W. Scheppegrell)

in treatment of laryngeal cancer ; results (D. B. Delavan)

- removal of foreign bodies from cesophagus by means of improved method of using (G. Hamilton)

results of treatment of cancer of larynx by $X$ rays (B. Delavan).

Ross (G. T.), mucoid cyst of left middle turbinal (abstract)

Rostock: usual methods of treatment and operation in Ear and Throat Clinic at Rostock (O. Koerner)

Roy (Dumbar), the value of exploratory puncture of the membrana tympani

Rorster (L. T.), report of a case of tonsillar ulcer of Vincent (abstract) 


\section{Index.}

Sarllle-nose: paraffin injection in case of so-called saddle-nose ( $F$. Alter) sulveutaneous (A. J. Martineau)

Saliva : import of salivary secretions in hay fever (D. B. Kyle)

DE SANTI (P. R. W.), case of tertiary syphilis of the larynx in a man aged twenty-six

man with growth on left rocal cord; case for diagnosis

540

- a report on four cases of acute septic inflammation of the throat.

with bacteriological examination of each

- case of unilateral right swelling of the thyroid gland in a woman asged fifty

a case of gumma of epiglotis
Sarcoma of larynx (primary) (C. Hödemoser)

Sarcomatrid tumour of septum (A. Brown Kelly)

Scarification, treatment of chronic hypertrophic pharyngitis hy (Escat)

Scarlatina: extensive destruction of bone in hereditary syphilis and scarlatina; demonstration of ease after operation (H. E. Jones)

SCHADLE (J. E.), on adenoid growths in children (abstract)

Scheppegrell (W.), on a case of cancer of the larynx cured by the $\mathrm{X}$ rays

SCHIFFER (F.). chronic suppuration of the middle ear: thrombosis of the cavernous sinus (abstract).

SchnIEGELow (E.), cituses of deaf-mutism .

"Schneeberger" snutf-powder: see Suuff-pouder.

Schromder: two cases of severe acute purulent median otitis caused by "Schneeberger" snuff-powder (abstract)

SCHWARTzE (H.), variations in the comse of the facial nerve and their significance in the mastoid operation (ahstract) .

Scientific treatment of deatness (Marare)

Scleroderma accompanying acute mastoiditis (M. Kamm)

Scleroma of trachea $(H$. vom Shroetter)

Serew perforator for maxillary antrum (W. D. Haslam)

SECORD (H. Large), a case of exophthahmos following mastoiditis (alsatract)

Secretions (nasal): import in hay fever (D. B. Kyle).

(salivary) : import in hay fever (D. B. Kyle) . superior and posterior semicircular canals, and greater part of restibule (Hugh E. Jones)

Sfmon (Sir Felix), a case of ohscure lardaceous-looking variable infiltration of the uvula, soft palate, and right arytænoid cartilage in a lady aced thirty

- a case of ulceration of the left tonsil, with acute and considerahle enlargement of numerous cervical lymphatic glands on both sides of the neck (? maligmancy) arly and unisual implication of rarious 39 cerebral nerves

- a demonstration of some experiments on the nature and specific: treatment of hay fever (abstrict $t$ ) . . - discussion on the operative treatment of malignant disease of the larynx (introductory remarks)

Septicamia : well-marked symptoms in case of hilateral alssess of septum (W. L. Culbert)

Septotome for use in Moures and other operations for deflection (L. H. Pegler)

Sequestrum comprising internal a dulitory meatus. superior and posterió: semicircular canals, and greater part of restibule (shown by H. E. Jones)

Serum (antidiphtheritic), treatment of diphtheria by intra-venous injection of (D. L. Cairns)

von Shroetrer (H.), on tracheal sclerema (alstract) 
SImoN (R. M.), a case of acute meningitis and cerelellar abscess (alostract).

. 447

Sinus, cinnula for washing out (Léry) . . . . . . . . .

(cavernous), thrombosis of ; chromic suppuration of middle ear

(F. Schiffers)

(frontal), abscess of, exhibition of patient operated upon three times for (M. Colliex)

Petersen) bilateral empyema cured by Killian's operation (W

disease: case of disease of hoth frontal sinuses (E. Furniss

Potter) case showing marked expansion (F. J. Steward) douhle antral and frontal simus disease; left sille cured

hy radical operation; question of operating on right side (Hunter Tod) empyema of (M. Collier)

antra (H. Tilley) empyema of frontal sinuses and of right maxillary antrum, with necrosis of the orbital wall (Moure) infundibular probe and cannula for (W. J. C. Nourse) gos. 418 (lateral) thrombosis; demonstration of case after operation (H. E. Jones) thromhosis septic, exposure and irrigation of inlb of internal jugular rein in operation for (Zaufal)
(maxillary) trepanation by way of inferior meatus (Vaquier)

(sigmoid), thrombosis of, with fatal pyamia in case of osteomyelitis of skull (A. Knapp) .

(sphenoidal), cutting forceps, new design for (P. Watson Williams) . empyema (chronic); opened (E. B. Waggett) prolie and cannula for (W. J. C. Nourse)
results of operation on. shown in case of nultiple simus suppuration $(\boldsymbol{H}$. Lambert Lack)

Sinus pressure causing tic douloureux and cranial neuralgia (S. F. Snow) Sinuses (accessory), abstracts of literature on $\quad .102,162,218,275.333$, $384,439,556,609,672$ anatomical method of demonstrating accessory cavities

of nose (G. Bruehl).

fronto-ethmoidal: choice of operation in (P. Jacques and A. Durand)

- (maxillary, true chronic), on a sign which is pathognomonic of,

(G. Mahu) .

$$
\text { (oculo-orbitary), complications of (Lapersonne) }
$$

- (sphenoidal, chronic), technique of surgical treatment of (C. Goris)

Skull : osteomyelitis, with empyema of nasal accessory cavities; sinus thrombosis; pyæmia; death (A. Knapp)

Skulls : choanæ in human skulls (S. Citelli).

SMI'H (S. MacCuen), exhibition of folding head-band see also Brïhl (G.), " Atlas and epitome of otology."

SNow (Sargent F.). conservatism in the treatment of acute mastoiditis (abstract) . 
Srow (Sargent F.). further observations of tic doulomeux and arinial neuralgia from intra-nasal and simus pressure.

Snuff-powder: two cases of severe acute purulent median otitis caused by ". Schneeberger " snuff-powder (Schroeder)

Soners (Lewis S.), the theory of cross-education as applied to the auditory apparatus (abstract)

Sore throat due to the pneumo-bacillus of Friedliander (Nicolle and Hebert)

Somml-transmitting apparatus of middle ear, tension anomalies of (C. J. Blake)

Spasm (clonic) of muscles of palate and pharynx, causing entotic tinnitus (L. H. Pegler) Pegler) of sott palate, causing oljective noises in pharynx (L. H.

Speech of the deat, method of dealing with and developing (J. K. Luve)

- progress in cure of ( $R$. Coen)

Spexcer (Walter G.), cise of epulikes or symmetrical swellings of the rmon at the posterior ends of the alveolar border in a female ayed thirty-seven.

SpIcer (Frederick), a case of accessory tragus (hilateral)

Sproer (R. H. Scanes), a readily improvised working molel to demonstrate the air-chamels and currents in the nasal carities in normal and impeder nasal respiration on paraffin injections in cases of sunken nose. a lintern demonstration showing the nomal fluctuations of airpressure in the upper respiratory tract.

Spine (smpra-meatil) : morphological value in antrectomy (O. Lenoir)

Stapers, ankylosis of the (Professor Denker).

STARCK: the etiology of diffuse dilatation of the asophagus (from the clinical point of view) (ahstract)

Stenosal theory of arlenoid deafness, difficulties and insufficiency of (D. M.Keown).

Stenosis dne to anyloid dereneration in larynx (W. Conrvoisier) B of larynx, tubercular, case treated hy tracheotomy (J. PriceBrown)

STEWARD (F. J.). a specinen of malformation of the (esophatsus -ase of frontal sinus lisease showing marked expansion

- a case with clonic contractions of the palate, aduluctors of vocal cords, and certain other muscles

a case of infiltration of soft palate (? cause)

Stewart (Purves). Ballance (C. A.), ind Ballance (H. A.), remarhs (m) the operative treatment of chronic facial palsy of leripheral origin (abstract)

STEWART (W. R. H.) a cise of nasal levermity in a womam

- a case of strumous ulcers of the mouth and tongue . . . 89 case of laryngeal ubstruction

Strockdale (E. Malcolm), two specimens and microseopic sections of epithelioma of the pinna

SToker (G.), ozone in chronic midille-ear deafness (abstract)

STotTe (Dr.), translation and a hidgment of Professor Denkers paper on ankylosis of the stipes

Stomatitis (streptococal) in Madairascar (Fontoynont and Jomran) .

Streptococcus: streptococcal glossitis and stomatitis in Madagiscal. (Fontoynont and Jouritran).

Stricture (malignant) of the upper end of the wsophasus. specimen (A. Logan Tumer)

Strurscher (H · • • • • •

Struschen (H. J. L.), acoumetry in micro-millemetres . . . . 34

STUART-Low (Mr.): exhilition of an anitomical tonsillotome. . . . . cases illustrating the heneficial effect of mucin in atrolpic rhinitis 
STucky (J. A.). presidential address at ninth annual meeting of the American Laryngological. Rhinological, and Otological Society

Student : see Medicril student.

SUAREZ DE MENDozA : loss of voice following thyrotomy (alustract) . $\quad$ oul

Sulyglottic thickening of right rocal cord (J. Donelan) . 4:-

Suppuration hehind mastoid and in posterior fossa associated with ear disease. but without perforation of memhrane (W. Pernewan) in temporal bone, toxamia from (H. Eulenstein) (multiple sinus), showing the results of operation upon the sphenoidal sinus (H. Lambert Lack)

(nasal, acute, or chronic), cases of pyogenic irain disease associated with or caused by (T. Hubbard) . of accessory cavities of nose (chronic) (A. P. Crocket) . of labyrinth (E. J. Moure). of middle ear (acute), treatment of (W. P. Phillips) - (chronic): thrombosis of cavernous sinus (F. Schiffers) . sphenoidal. ('hronic (D. McKeown)

Suppurations in labyrinth (V. Hinsherg)

Supra-nasal cyst in an infant (V. Wyatt Wingrave) .

Surgical practice in our special departments

Suture, masto-squamosal (Aderman)

Swellins. interarytanoid psencio-pachydermic, with chronic laryngitis. probahly due to purulent rhinitis (J. Dumdis Grant)

- in post-nasal space (E. Furniss Potter) of arytmoids, accompanying double abluctor paralysis (C. A

Parker) of larynx (right side), case for diagnosis (H. J. Davis). of mucous membrane (larges) in interarytanoid resion (so-called interarytanoid pachydernia) (H. Tilley)

$$
\text { of thyroid gland (unilateral right) (P. R. W. de Santi) . }
$$
post-pharyngeal (E. B. Waggett)

Swellings, symmetrical, of gum at posterior ends of alveolar border (epulides) (W. G. Spencer)

Sxmonos (Charteis J.). case of paralysis of left vocal cord due to leadpoisoning .

Symptom-complex: new iullar symptom-(complex (P. Bomier)

Syphilis (hereditary): extensive destruction of lome in hereditary syphilis and scarlatina ; demonstration of case after operation $(H . \mathrm{E}$. Jones)

_- hereditary : specific perforation of anterior jillat of fances (J. Dundas Grant) (5) in case of perforation of nasal septum (J. Donelam). of larynx, pharynx, and soft palate. combined with tuliereulosis

(V. Wyatt. Winerave)

- of mucous memhiane of mouth and throat : tratment (A. Lieven) (tertiary), adhesion hetween soft palate and posterior pharyngeal

wall. the result of tertiary syphilis (P. H. Alererombie)

Talies: case with early and musual implication of corelral nerves (Sir F. Semon) .

Tâche spongieuse : morphological value in antrectomy (D. Lenoir)

Taste filres and their independence of the nerrus trigeminus $(H$. Cushing) .

Temporal lone: morphology and development (A. Paterson)
stereograms of sections of (J. K. Love) 166 surical relations of facial nerve in (H. E. Jones) 


\section{Index.}

$\operatorname{xxxix}$

Tempral hone: technique of operations on temporal hone in suppurative mirlile-ear lisease

Anmual Meeting on discussion at British Mealcal Association toxituia from suppuration in temporal hone (H. Eulenstein) . 109 tuberculosis of rlinical dianosis and suruical treatment, considered with peference to the pathology and morlid anatomy of the disease (W. Jitisem Horne) tulerculosis: specimens of (A. H. Cheatle)

Temporal bones remored from patients who died of tuberenlous meninuitis (A. H. Cheatle) .

Tempor-sphenoidal abscess : see Alscess (temporo-sphenoidal).

rension anomalies of the sound-transmitting apparatus of the middle air (C. J. Blake)

Teratem of ear (W. C. Buislin

TÉTRop : on resection of the trachea (alstract)

Theisen (Clement F.), a catse of lipoma of the tonsil .

Theralentics, alistracts of literature om

Thickening (celematous) of litrynx and palate (H. Lambert Lack)

- (subglottic) of right rocat cord (J. Donelan) . . 4.5

Thorse (Attwool), case of epithelioma of the larymx in a man aged sixty

Throat. inflammation, acute septic. four ases with lacteriolosical ('xamination of each (P. R. W. de Santi) short operations ; choice of ancesthetic in (J. H. Chaldecott) syphilis of mucous membrame of : treatment (A. Lieven) se also Sore throit.

Throminosis of cavernous sinus in caste of chronic suppuration of middle $\operatorname{arr}$ (F. Schifters) of cavernous simuses (S. Lorlye) of lateral simms: demonstation of case after operation (H. E. Jomes) of simoid sinus, with fatal premia, in case of osteo-myelitis of skull (A. Knapp)

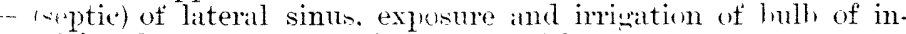
termal jugular vein in operation for (Zanfal)

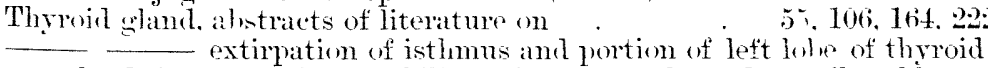
mlamr in case of immolility of left rocal cord attributalie to frromchocele (J. Dumrlas Grimt)

Thyroil grafts (Christiani) (abstract)

Thyoril tumowr at lase of the tongue. two cases (Gaudier and Chevalier)

Thyrotomy for epithelioma of larynx: two cases remaining well two Fears after operation (E. S. Yonge)

in removal of large papillomat of right rentricular hand (E. B. Wargett)

Tic donlourem from intra-nasal and simus pressure (S. F. Snow)

TILLex (Herlert), case of vascular naso-pharyngeal filmomal of extensive origin finally removed hy a combined operation throush the soft and hard palate and extensive removal of anterior wall of left supramaxillary lone; patient and specimen shown

- a patient from whom a lare hyperostosis of the left aural meatus hat heen removed

a case of advanced and inoperable epithelioma of the epighottio with secondary infection of cervical wands. Exhibited to illustrate relief ohtained l,y removal ly " morellement" of primary spowth through the mouth. 
TruLey 'Herbert) a case illustrating tuherculous disease of the natial cavities - case of liarge swelling of the mucous membrane in the interarytænoid region (so-called inter-arytanoil " pachydermia ") .

- a case illustrating an operative procedure for the relief of almost complete adhesion of the soft palate to the posterior pharynutal wall, the result of tertiary syphilis

- a case of chronic empyema of hoth frontal sinuses and maxillary antra ; radical operations to illustrate the almost complete olliteration of the maxillary sinuses following the radical operation

- a case of pedunculated tumour growing from region of the right tonsil

- discussion on operative treatment of malignant disease of latynx

- discussion on the technique of operations on the temporal lione

in suppurative middle-ear disease

part played by nose and naso-pharynx as a source of genemil septic infection in two sets of circumistances (discussion on the upper respiratory tract as a source of systemic infection).

- discussion on local use of formalin in treatment of nasal polypi

Timnitus (clicking), oljective (C. Baber) (entotic) (L. H. Pegler)

(H. Tilley) . due to clonic spasm of muicles of palate and pharym

Tobacco, nerve-deafness dine to (V. Wyatt Wincrave)

TOD (Hunter), case of left antral empyema. followed by abscess of hard palate and of septum nasi

case of double antral and frontul sinus disease: left side cured

by radical operation: question of operatine on the risht side

a case of laryngitis hypertrophica in a girl aged twenty-one. following prolonged nasal trouble

- a case of polypoid tumour of the nasal septum in a woman ased thirty-three; three months duration; microscopical sectiom exhibited ; diagnosis (?)

Tongue, cancer of, early diagnosis (H. T. Butlin) .

- unsuccessful operations (H. T. Butlin) epithelioma. in a single woman aged twenty-four (A. H. Burt) (inflammation of) : see Clossitis.

involved in case of nævus (P. H. Alercrombie)

paresis of (sliegh), in case of paralysis of the alductors at the

vocal cords and of palatal muscles (J. Dumdas Grant)

- thrroir tumour at the base of the tongue two cases (Gaulier

and Chevalier)

ulcerating growth of left tonsil, side of tongue and anterior

fancial pillar ( $\mathrm{H}$. FitzGerald Powell) .

ulcers of, strumous (W. R. H. Stewart)

wandering rash on tongue (Mayo Collier)

Tongue-depressor for exposing tonsil (C. Baher)

Tonsil, epithelioma of pharynx and tonsil: specimen (V. Wyatt Wingrave)

rave

histology of tonsils in relation to disease (J. L. Goodale)

(left), tuberculosis (acute); specimen and section (F. H. West. macott)

nlcerating growth of left tonsil, sirle of tongue, and anterior fancial pillar (H. FitzGerald Powell)

ulceration, with acute and considerable enlargement of

numerous cervical lymphatic slands on lioth sides of the neck

(: malignancy) (Sir F. Semon) (lingual), hypertrophy of (P. H. Ahererombie)

lipoma of (C. F. Theisen) .

mucous patches of tonsils (H. Lamiert Lack)

(right), pedunculated tumour growing from region of (H. Tilley) 


\section{Index.}

Tonsil: tongue depressor for exposing (C. Baber) ulcer of. containing tubercles, which yielded to antisyphilitic remedies (H. Lambert Lack) . ulceration of (R. Lake)

Tonsillitis, relation to inflammation of the vermiform appendix (Hans Weber:

Tonsillotome, anatomical (shown by Mr. Stuart-Low)

Tonsillotony : case following hilateral adductor paralysis (V. Wyatt

Wingrave) .

Tooth. expectoration of thirteen months after inhalation into the lung (W. E. Carnegie Dickson)

Toxamia from suppuration in temporal bone (H. Eulenstein)

Trachea, ahstracts of literature on

(A. Logan Turner) .

-.. - ozenat of, causing dyspncea (Dupond)

-... resection of (Tétrop) scleroma of (H. von Shroetter)

Tracheotomy in treatment of case of tubercular stenosis of larynx (J. Price-Brown)

Cll-standing lupus necessitating (C. Nourse)

Tragus, accessury, hilateral (F. Spicer)

Transillumination of maxillary intrum and of eye (C. Ziem)

Tratuma (f) in al case of perforation of nasal septum (J. Donelan)

Trepanation of maxillary sinus ly way of inferior meatus (Vaquier)

Trow (C.). mastoiditis due to monococ"us (abstract) .

onsenital; specimen

Tulercular laryngeal stenosis: case treated by tracheotomy (J. PriceBrown)

ulceration (primary) of nasal septum (E. B. Wascett) .

Tuherculosis. human and hovine (Nathan Raw) of ear; bihliography (primiry); hihliography

(M. A. Goldstein) followed hy mastoiditis; report of four cases specimen from a case of seneral miliary tuberculosis with primary focus in temporal bone (W. Johson Horne) of ear, nose, and naso-pharynx; discussion (Urhan Pritchard. C A. Ballance, A. E. Cunber rateh. A. L. Whitehead, Hush Jones, A. Cheatle)

- - diagnosis and treatment of tuberculons disease of the middle ear and its accessory cavities (W. Milligan)

cases of middle-ear" suppuration, with an analysis of the result

haring special reference to the presence of tubercle and "acid-fist"

bacilli (V. Wyatt Wingrave) secondary, case of (A. H. Cheatle)

- two specimens (C. H. Fagrge) of larynx (C. Nourse) (R. Lake). pharynx and soft palate combined with syphilis (V. Wyatt of temporal hone: clinical diagnosis and surgical treatment (W. Jolison Horne) . 
Tuherculosis of left tonsil (acute); specimen and section (F. H. Westmatcott) - removal of epiglottis for tuberculous disease (Richard Lake)

Tuberculous disease of ear and naso-pharymx. specimens and microphotographs of (W. Milligan) . clands, perforation of cesophagus ly (C. Riviere)
pramulomat of larynx (V. Wyatt Wingrave).
pachydermia from processus rocalis; microscopical section (R.
Lake)

Tules (fixed) and bosterior part of septum nasi (Bellevue)
Tumnle for cases of difficulty in "iécannlement " (Cuno)

Tumour (aldominal) associated with tmom of the meatus (A. H. Cheatle)

-- of sumerior maxilla (C. F. Forshaw)

_- of meatus: case associated with abdominal tumour (A. H. Cheatle)

- of nose (W. H. Kelson)

\section{(C. Nourse); (V. Wyatt Wingrave)}

(A. H. of septum, sarcomatoid (A. Brown Kelly)

of vestilule of nose ( $\mathrm{E}$. Cresswell Baber)

(perlunculated) growing from resion of rimt tonsil (H. Tilley)

thyroil, at base of tongue: two cases (Gamilier and Chevalier). tuberculous, on posterior part of septum nasi (Bellevue)

Tuning-forks (Edelmann's $\mathrm{C}$ and $\mathrm{G}$ ), objective uniform measure of hearing as supplied by amplitude of viluation of (Prof. Ostmamn)

Turbinal (inferior), papilloma from recrion of ; microscopic specimen ( $R$ Lake) (left middle), mucoid cyst of (G. T. Ross)

Turlinate horly (inferior), restoration by paratin, in treatment of atrophic rhinitis ( $\mathrm{R}$. Lake) (left inferior), new growth involving (R. Lilke)

(right inferior), new growth removed from; section (R. Lake) exhibition of section of ( $R$. Lake)

Turlinotony (partial), unusual experience after (L. H. Perler)

TURNFr (A. Lugan), a series of anatomical preparations demonstrating the artificial production of celema of the larynx.

- - a specimen of ahnormal narrowing of larynx and trathea, prohably consenital .

- - a specimen of malignant stricture of the upper end of the asophagus.

- - liscussion on the technique of operations on the temporal hone in suppurative midlle-ear diseast

discussion on the upper respiratory tract as a source of systemic infection.

Tympanum : see Membrana tympani.

Ulere : see also Malignant ulcer.

(of tonsil) : tonsillar ulcer of Vincent (L. T. Royster)

Ulcerating srowth of left tomsil, side of tongue, and anterior faucial pillar (H. FitzGerald Powell) .

Ulceration in pharynx and larynx, recurring, thought to he herpetic (E. Fumiss Potter)

of soft palate (L. A. Lawrence)

of tonsil (R. Lake)

(primary tuhercular) of nasil septum (E. B. Wagrett) 
VAQEIER: trepanation of the maxillary sinus ly way of the inferior meatus (abstract)

VACurAs (Major J. C.. I.M.S.) report of micruscopical examination of Captain O'Kinealy's case of localised prorospermosis of the mucous membratue of the septum nasi .

Vein (internal jugular) : see Juynlar rein. .

Ventricular hand (right) : papilloma (large) removed ly thyotomy (E. B. Wawert)

Vermiform appendix, infiammation of : sep Appendicitis.

Vertiuo (nasal) simulatinus epilepsy (E. Woakes)

Vesis (Lucien). and LERor (Ranul). on the hroienic treatment of exophthalmic goitre (ahstract)

Vestilnle: sequestrum comprising internal auritors meatus, superior and posterior semicircular canals. and sceater part of restilule (Humh E. Jones)

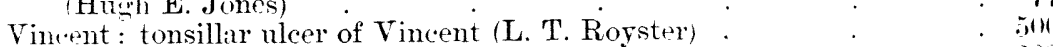

VIxRACE (Demis). a case of lupus (?) of nose and face . 3:3

Vocial cord (left), wrowth on: case for diannosis (P. de Sinti) . B]

immobility, attributable to hronchocele (J. Dundas Giant) papillated thickening of. in iase of chronic layyngitis (J. Dumias Grint)

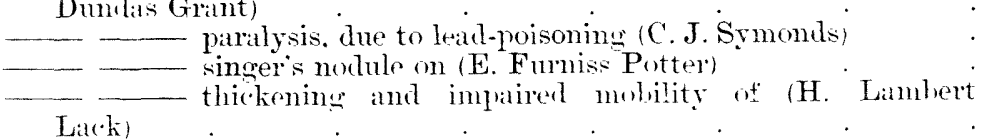

(right), fixation of (W. J. Horne) when cperating on (H. Lambert Larck) sulglottic thickening of (J. Domelitn).

Vocal corris. clonic comtraction of arluctors of (F. J. Strward)

- paralysis of the ahductors and of the palatal muscles, with slight garesis of the tomgue (J. Duniais Grimt)

Voice: losin of roice following throtomy (Suarez de Mendoza)

Voss: three cases of encephalitis in comnection with otitis media (alistract) .

WArritrT (E. B.), case of malignant disease in the neighbourhood of the right Eustachian tule in a man aged sixty-nine .

a case of chronic empyema of sphenoital sinus: opened - a large papilloma of the right ventriculat band in a woman aged

- cise of primary tubercular ulceration of nasal septum

WALWAM (Willian Johnson) : obituary notice (with list of literary contrilutions to laryngology and rhinology

Werer (Hans), the relation of tonsillitis to inflammation of rermiform appendix (abstract)

W ESTERMAN (Dr.), an objective uniform measure of hearing as supplied by the amplitude of vibration of Edelmann's $C$ and $G$ tunins-forks. By Professor Ostmann. (Author's ahstract. translated ly Dr. Westerman)

WEstracotT (F. H.), a specimen and section of acute tuherculosis of the left tonsil from a man aged thirty-two.

WhitehEAD (A. L.), discussion on tulereulosis of ear, nose. and nasopharynx

Wilde`s incision: inefficiency for otitis merlia suppurativa (J. M. Ray)

Williars (Chisholm). high-frequency currents in the treatment of some diseases (review)

WrLtrans (Patrick Watson), a new design for sphenoidal sinus cutting. forceps 
WILLIAas (Patrick Watson), on the position of laryngology and otolowy in the medical student's curriculum (Presidential aldress, Section of Laryngology and Otolony. British Hedical Association Ammal Meeting, 1903$)$

- discussion on operative treatment of malignant disease of larvnx

on the technique at operations on the temporal lone in suppurative middle-ear disease intection on the upper respiratory tiact as a source of systemic:

on local use of formalin in treatment if nasal polypi adenoid deafness

Wilson (R. A.). lodgment of a foreign liody in the air-parisates for seventy-two days (ahstract)

Wringrave (V. Wyatt), case of pachydermia laryngis a case of larymseal growth in a mun ased fifty

on the nicroscopical examination of the discharge in one humber (ases of midale-ear suppuration, with an analysis of the results. having special reference to the prestence of tuhercle and "acid-fist" hacilli

_... tolacco nerve-deifnes

reply to discussion on tulerculosis of ear, nose. and naso-pharynx

-... - a case of liryngeal and pulmonary tuberculosis in a man areal forty-seren

-... a cystic eholest atoma firom the lett supra-consillar fossa

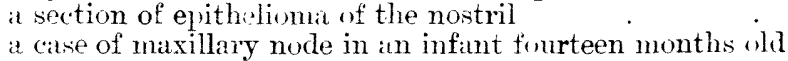

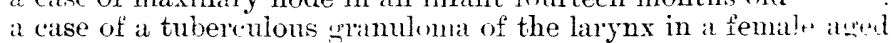
twenty-six .

-... case of bilateral alductor malasis in a cirl aged fourtam following tonsillotomy

- case of lupus of larynx in a lioy ager fourteen

- case of combined syphilitic and tuher(alous disease of langnx. pharynx, and soft palate in a womam aged forty .

- - a case of lupus of nose, palate. and larymin in female and twenty-three

- microscofic examination of tmour of nise Mr. Chichele

Nourres case)

-.. - specimens illustrating the histolusy of the accessing :-inuses the external auditory meatus.

\section{- _. - a slinht modification of Mones operation}

a case of supma-nasial cyst in an infiant fifteen months old

- a case of persistent superficial nasial hy geramia, cured by removal of adenoids, in a male ageal twenty-one.

- microcopic specimens: (1) naso-pharyngeal filoma: (2) maliotonsil: (4) epithelioma of the external aulitory meatus.

WoAKEs (Edwarl), case of nanal vertiso simndating epilep'sy (alsinact)

Wouf : contribution to the etiolosy of carcinoma of the asoplandus (alistract).

WolfF ( $\mathrm{T}$.), the contagiousness of a unte ot itis merlia (alstract)

WoOds (R. H.), discussion on glepative treatment of malignant disease of $\operatorname{larynx}$.

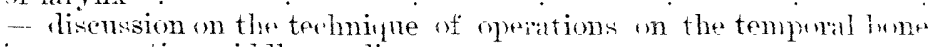
in suppurative mirdle-ear disease . . discussion on the upley respiratory trat as a solures of systemin. infection 
Woons (R. A.) discussion on difficulties and insufficiency of stenosal therry of adenoid deatness . . . . . 671 Wool tidy

$\mathrm{X}$ rays: see Rivitgen rays.

YoxaE (Eugene S.). discussion on prerative treatment of malignant disease of larynx . . . . . - two cases of epithelioma of the larynx remaining well two years after olevation (thyrotomy) . . . 4911

ZALFin: exposure and irrigation of the bulh of the internal jugular vein in the operation for septic sinus thromleris (ahstract)

Z:D? MYEHLEN (A.). after-treatment of radical onerations without packing (ahstract) 
